\title{
Performance Simulation of a Modified Geothermal Grain Dryer Based at Menengai Well 3 in Kenya
}

\author{
Levi Kulundu', Hiram Ndiritu², Gareth Kituu'², James Kimotho ${ }^{2}$ \\ ${ }^{1}$ Mechanical Engineering Department, Pan African University Institute for Basic Sciences, Technology, and Innovation, Nairobi, \\ Kenya \\ ${ }^{2}$ College of Engineering and Technology, Jomo Kenyatta University of Agriculture and Technology, Nairobi, Kenya \\ Email: levikulundu@gmail.com
}

How to cite this paper: Kulundu, L., Ndiritu, H., Kituu, G. and Kimotho, J. (2022) Performance Simulation of a Modified Geothermal Grain Dryer Based at Menengai Well 3 in Kenya. World Journal of Engineering and Technology, 10, 59-87. https://doi.org/10.4236/wjet.2022.101004

Received: January 10, 2022

Accepted: February 22, 2022

Published: February 25, 2022

Copyright $\odot 2022$ by author(s) and Scientific Research Publishing Inc. This work is licensed under the Creative Commons Attribution International License (CC BY 4.0).

http://creativecommons.org/licenses/by/4.0/

\begin{abstract}
Geothermal energy can be effectively utilized for grain drying to reduce carbon emissions and also cut operational costs associated with conventional methods. The main challenges encountered in the use of the geothermal grain dryer, such as in Menengai, Kenya, include uneven grain drying and long throughput times. Grains near the hot air inlet dry at a faster rate compared to those near the exhaust end. Therefore, the grains must be recirculated within the dryer to achieve uniform moisture distribution. Grain recirculation is energy-intensive as it utilizes electricity running the elevator motors in addition to the suction pump. A Computational Fluid Dynamics (CFD) model was developed to study the airflow pattern and its impact on drying of maize. The model was simulated in ANSYS 21 and validated using experimental data. Finite volume discretization method was employed for meshing. Pressure-based segregated solver was used in the Computational Fluid Dynamics (CFD) simulation. Also, K-Omega turbulent model was used for enhancing wall treatment. The findings indicate that non-uniform hot air distribution across the grain buffer section causes uneven drying. Introducing filleted flow-guides results in a relatively uniform velocity, temperature, and turbulence kinetic energy distribution across the dryer. The average velocity and temperature magnitudes in lower compartments increased by $153.3 \%$ and $0.25 \%$ respectively for the improved dryer. In the upper compartments, the velocity and temperature increase were $176.5 \%$ and $0.22 \%$ respectively.
\end{abstract}

\section{Keywords}

Filleted Flow-Guides, Flow Distribution, Geothermal Grain Dryer, Computational Fluid Dynamics 


\section{Introduction}

Grain drying is one of the viable direct geothermal uses in Kenya as agriculture is the backbone of the country's economy. However, geothermal grain drying in the country is not fully developed due to financial, technical, and infrastructural challenges. In 2019, the Geothermal Development Company (GDC) installed a pilot scale, batch type grain dryer in Menengai Well 3 [1]. The drying energy is provided by geothermal fluids through a heat exchange process with fresh water. The suction fan blows ambient air through the heated fresh water tubing to the grain dryer. Hot air is then pumped into the dryer at a temperature of between $45^{\circ} \mathrm{C}$ to $55^{\circ} \mathrm{C}$ [2]. The dryer has four compartments with evenly spaced fins that guide air flow through the grains. However, the main operational challenges encountered include long throughput times and uneven grain drying. This entails recirculating the grains within the dryer to achieve uniform moisture content. The need for grain recirculation to resolve uneven drying increases throughput time and power consumed by auxiliary equipment such as elevator motor, suction pump, and hot air pump.

The use of geothermal energy for grain drying is relatively cheaper than other conventional means such as fossil fuels and electricity [3]. However, direct geothermal use in grain drying is not fully developed. Only 22.4 MW out of 10,000 MW is utilized in the agricultural sector [4]. Operational and infrastructural challenges impede the use of geothermal energy for grain drying in Kenya. Also, geothermal grain drying efficiency is considerably low and ranges between 25 and 50\% [3]. Geothermal grain dryers utilize low to medium enthalpy brine that may not be viable for electricity generation [5].

Several studies have been conducted on efficient utilization of geothermal energy for grain drying. According to Abdullah and Gunadnya [6], humidity, temperature, air flow, and equipment design are the primary parameters that influence the rate of grain drying. Increase in the rate of air flow improves drying efficiency [6]. While brine can be effectively used for drying, the operational efficiency depends on drying temperature and air flow rates [7]. Low temperature and velocity distribution increases the throughput time and operational costs. Other factors that impact drying rate include grain depth, exposure time, relative humidity, initial moisture content, and grain size. The turbulent intensity may also influence grain drying rate. Studies show that when the turbulence intensity is high, then the air flow rate does not affect the rate of wheat drying. However, air flow rate has a significant impact on the efficiency of maize and rice drying [7].

Studies on "reducing energy use in grain dryers" illustrate a design of a heat recovery system to improve operational efficiency [8]. Based on the preliminary investigations, it was estimated that a grain dryer wastes over 40 percent of its energy to the environment. By reusing and reducing waste heat, the operational costs would reduce by 40 percent [8]. The study recommended grain cooling through dehydration or in-bin cooling, use of efficient dryer, and reclaiming heat 
from the dryer exhaust air [8]. Given that the fun has the highest exergy destruction in a grain drier, recirculating exhaust air significantly reduces energy loss to the environment [9].

Conventional grain drying has the disadvantage of significant environmental pollution and high energy consumption [10]. Investigations show that the energy consumed in drying is higher than the energy usage in producing agricultural products [11] [17]. Coal and other non-renewable energy sources are primarily used for grain drying, thereby causing heavy pollution [10]. Continuous hot air drying used in conventional systems has low efficiency and long throughput times [12]. Also, significant energy is wasted along with the expelled humid and warm air [13]. A two-stage supply of hot air in the dryer improves the overall operational efficiency [10]. Other studies indicate that a closed-loop heat pump has a higher drying efficiency than the conventional dryers [14].

The source of drying energy has an impact on operational efficiency. The use of Liquefied Petroleum Gas dryers result in $6.14 \%$ energy savings compared to the conventional hard coal [15]. A wide range of energy sources such as solar, biomass, and fuel gases have been investigated for enhanced energy savings and reduced emissions. Use of clean electrical energy and recirculation of exhaust air improves energy savings while also cutting operational costs [16] [17].

The reviewed literature provides insights on the factors that influence grain drying. They also recommend ways of improving grain drying efficiency. However, the literature does not provide solution to uneven grain drying. Also, the option of recirculating exhaust air may not be viable for batch type driers. The exhaust air has high humidity and would increase moisture content in the grains.

A CFD model was developed to study the effect of geometry modification on air flow distribution through the dryer and simulated in ANSYS Fluent. An improved geometry with flow-guides at the inlet section for directing hot air distribution in each compartment was modelled. Air flow parameters such as velocity, temperature, and turbulence kinetic energy were monitored in the model. The objective of the modification was to improve drying efficiency by increasing the turbulence kinetic energy, temperature, and velocity distribution throughout the dryer. The air flow distribution for the modified model was then compared with the current design. The CFD simulation results show that incorporating air flow-guides in each compartment increases temperature, velocity, and turbulence kinetic energy distribution throughout the dryer.

\section{Materials and Methods}

\subsection{The Geothermal Grain Dryer in Menengai}

The dryer is located at Menengai GDC station, and utilizes thermal energy from Menengai well 12 (MW-12) and has a maximum handling capacity of 6 tones [1]. Figure 1 shows the main operational parts which include the heat supply system, dryer, storage bin, wet bin, and elevator motors.

The elevator motor loads the wet grains to the dryer, through the dryer chute. 
Brine is supplied to a heat exchanger at a temperature of $90^{\circ} \mathrm{C}$ and leaves at $76^{\circ} \mathrm{C}$ [2]. Hot geothermal water provides the thermal energy that heats fresh water from room temperature to $78^{\circ} \mathrm{C}$. The hot water is then supplied to the radiator at a temperature of between $78^{\circ} \mathrm{C}$ and $55^{\circ} \mathrm{C}[2]$. Figure 2 below shows the heat exchange system between the brine and fresh water.

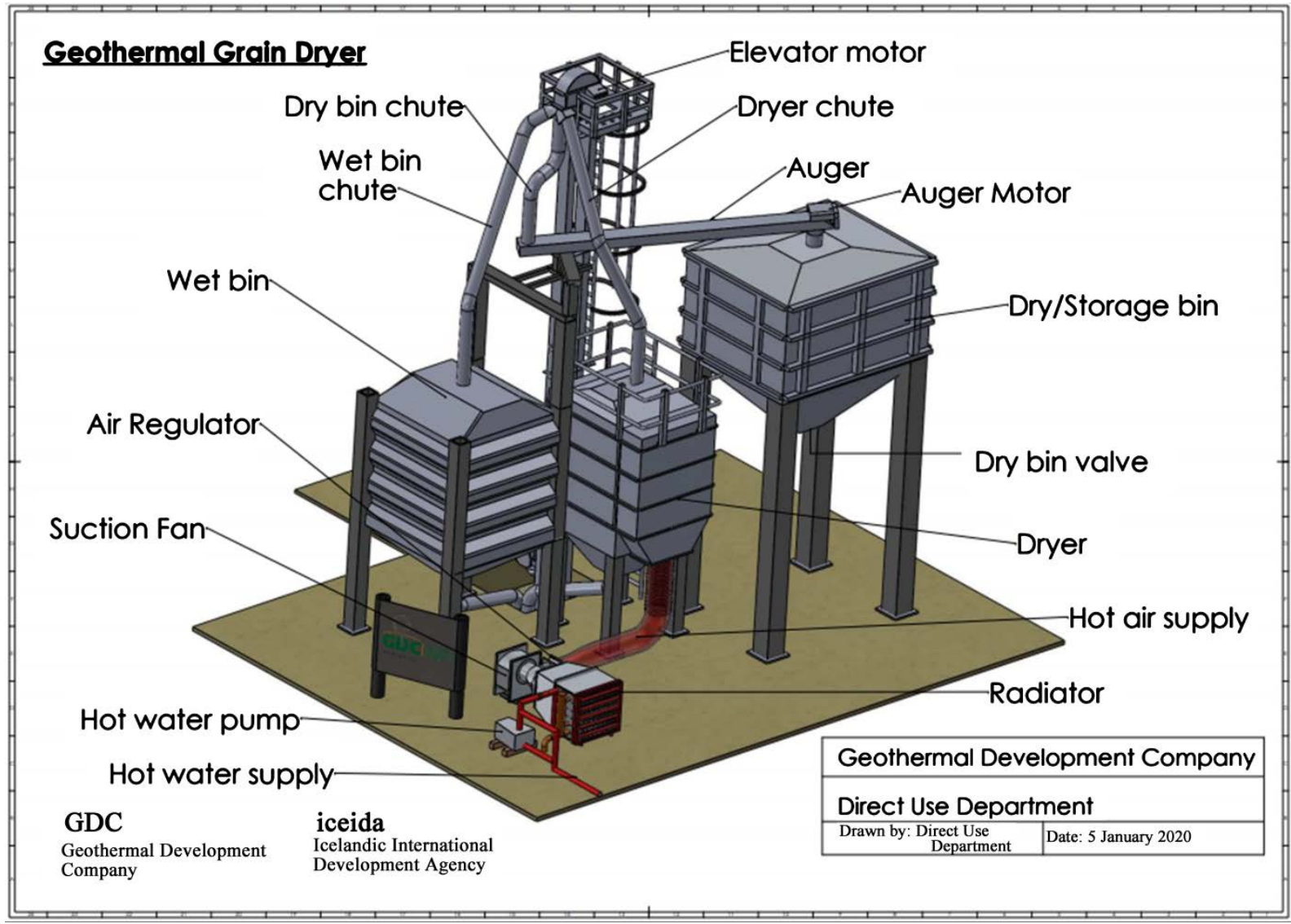

Figure 1. Parts of the Geothermal grain dryer in Menengai [2].

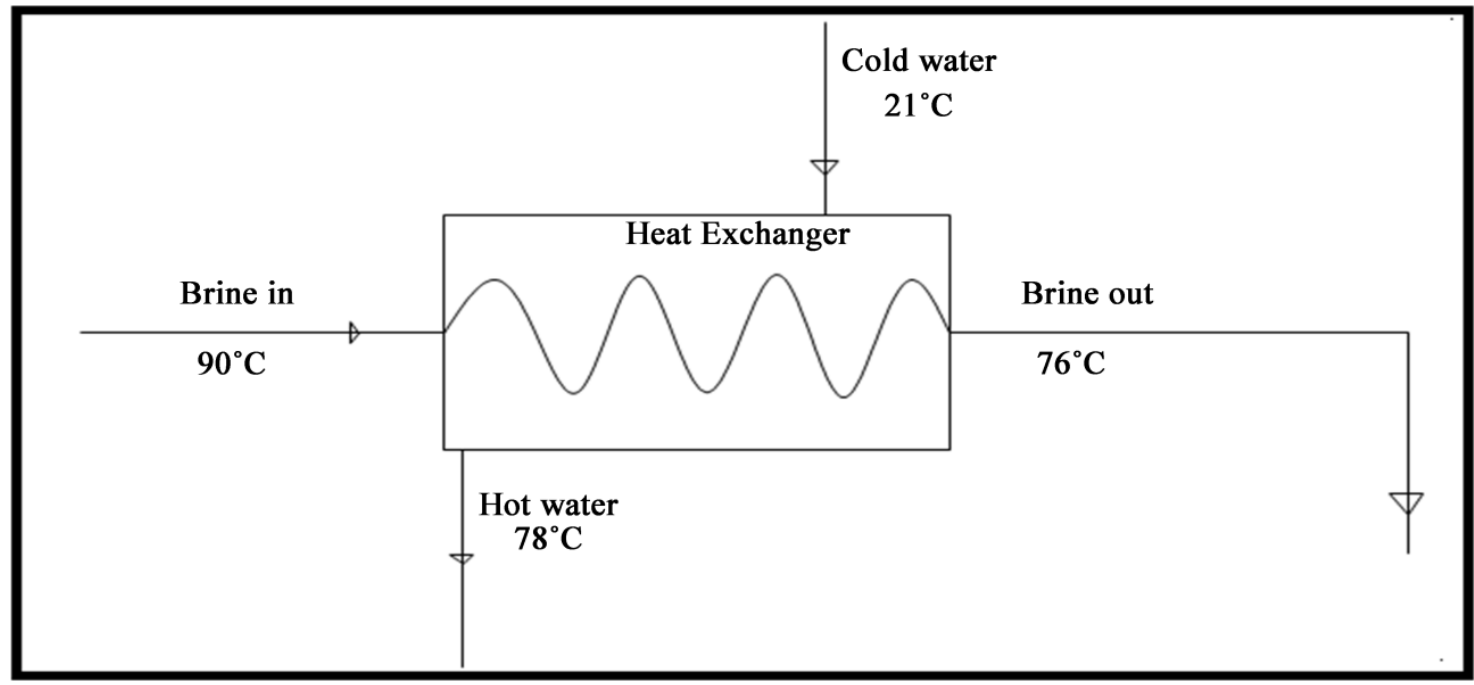

Figure 2. Heat exchange between fresh water and brine. 
A suction pump then blows ambient air through the hot water tubing to the dryer. The supplied hot air enters the grain buffer section in the drier through evenly spaced openings across the four compartments. After attaining the desired moisture content, the dried grains are loaded to the storage bin.

\subsection{Data Acquisition and CFD Modelling}

This study entailed both ANSYS Fluent simulation and physical experiments to validate the model. Physical experiments were conducted to determine the extent of uneven grain drying and hot air distribution. A calibrated Moisture Analyzer, Serial No.0202777, superpoint, manufactured by Supertech Agroline Ltd, Denmark, was used to measure the moisture content (wet basis) in each compartment. Validated temperature-humidity meters, UT333, manufactured by Uni-Trend Technology, China, were used for measuring the temperature and relative humidity of air at the inlet and exhaust sections.

The first experiment involved drying 2.7 tons of maize with initial moisture content of $21.1 \%$. The grains were filled up to half of the third compartment. Grain drying parameters such as the hot air supply rate, temperature distribution, relative humidity, time, and grain moisture content were monitored throughout the experiment. The rate of air supply to the dryer was derived analytically based on the suction pump power ratings and the cross sectional area of the hot air inlet. The hot air was supplied at an average speed of $1 \mathrm{~m} / \mathrm{s}$ and at a temperature of $50^{\circ} \mathrm{C}$. Grain drying began at $1: 40 \mathrm{pm}$ and moisture contents were measured after every 20 minutes. Due to uneven drying, grain recirculation began after two hours. The mixed grains were then sampled after every 20 minutes to measure the moisture content. The data was manually collected from the moisture analyzer and temperature-humidity meters. They were then tabulated and analyzed in Microsoft excel to determine the trends.

The second experiment was conducted to determine temperature distribution across the dryer without loading grains. Temperature magnitude in all the four compartments and exhaust sections were recorded after every 10 minutes. The goal was to study air distribution in the dryer without the load and also to provide validation data.

Detailed dimensions of the geothermal grain dryer were collected from physical measurements and then modeled in Autodesk Inventor. The study only focused on the dryer section and did not include the wet and storage bin as the goal was to model air flow in the grain buffer section. Figure 3 shows parts of the dryer geometry that was modeled in Autodesk Inventor. It has the air inlet and outlet sections and four compartments in the grain buffer section.

The grain dryer has four compartments with evenly spaced fins that guide air flow through the dryer. Figure 4 shows the dimensions of the dryer, including the grain buffer section. The fins provide sufficient space for air to penetrate through the grains. Consequently, the design allows sufficient interaction between the grains and hot air, thereby improving drying efficiency. 

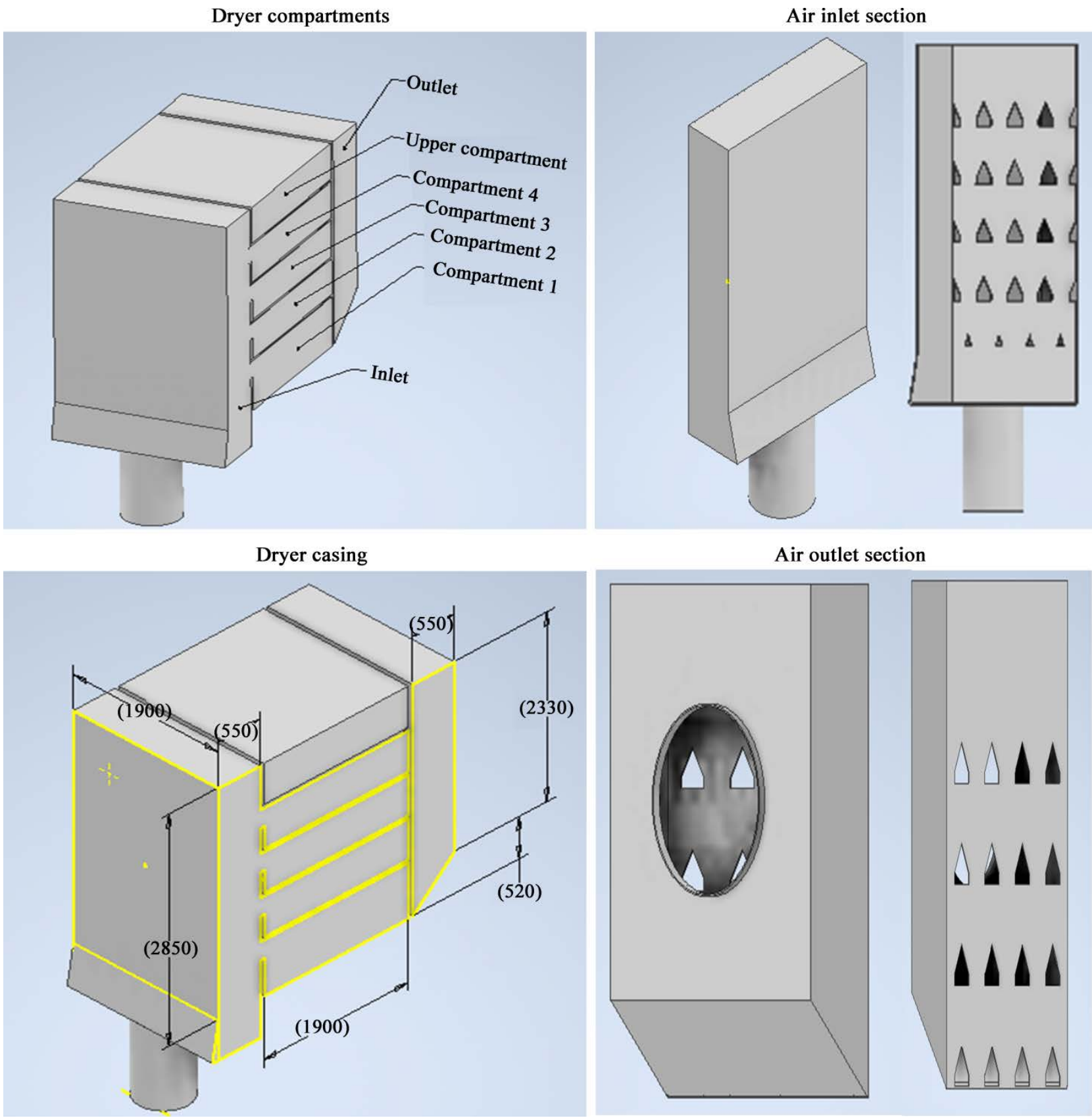

Figure 3. Parts of the modeled dryer.

\subsection{CFD Modeling}

The 3D CAD geometry of the dryer was developed in Autodesk investor. It was then imported to ANSYS Fluent for flow modeling. Air flow through the dryer was modelled without incorporating the grains to determine the velocity, temperature, and turbulence kinetic energy distribution across the dryer. Flow distribution was modeled under steady state conditions as mean flow parameters at the inlet and outlet compartments did not significantly change with time. The velocity, temperature, and turbulence kinetic energy distribution across the dryer were recorded in vectors and contours. 


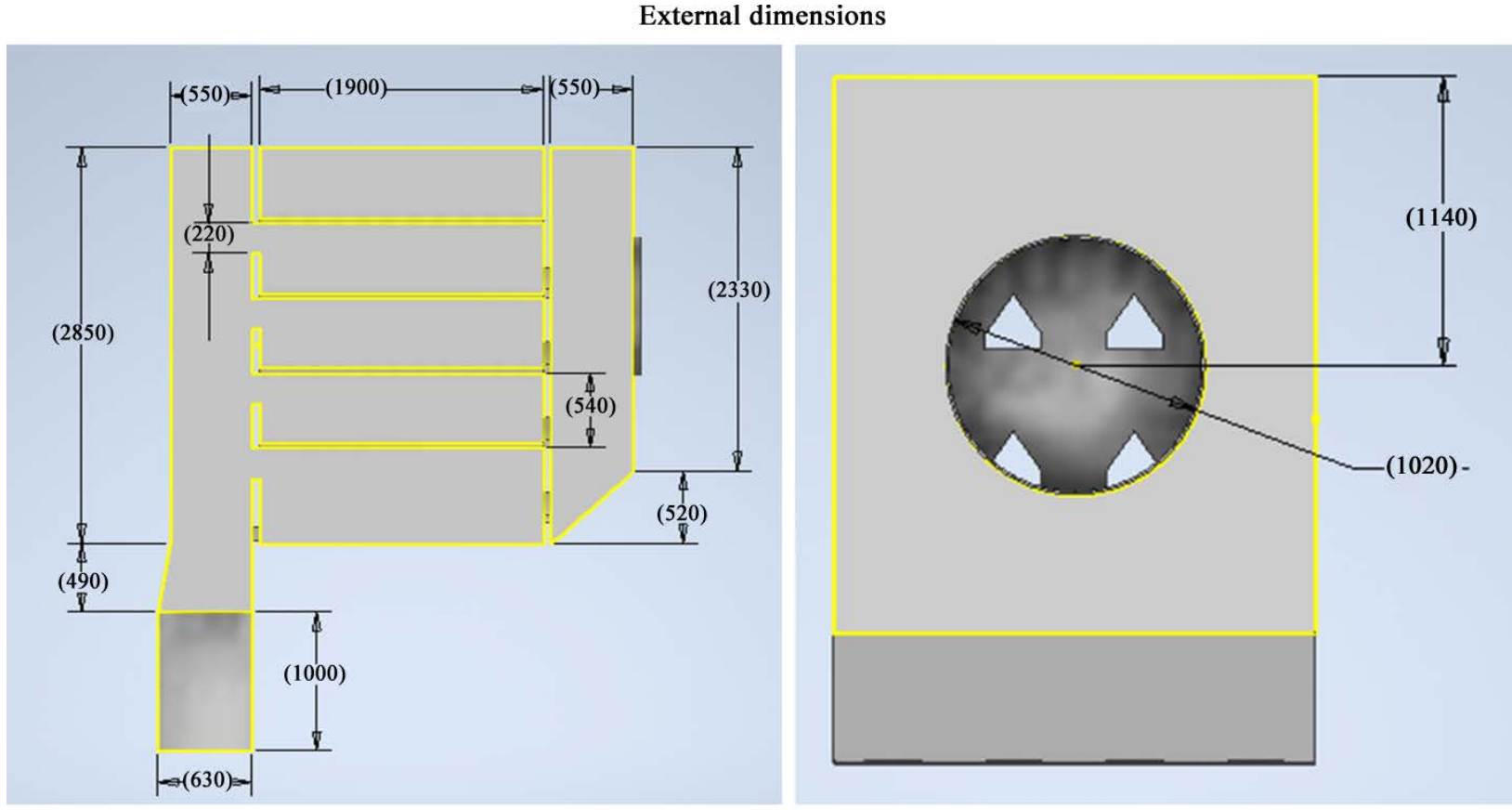

\section{Grain buffer section}
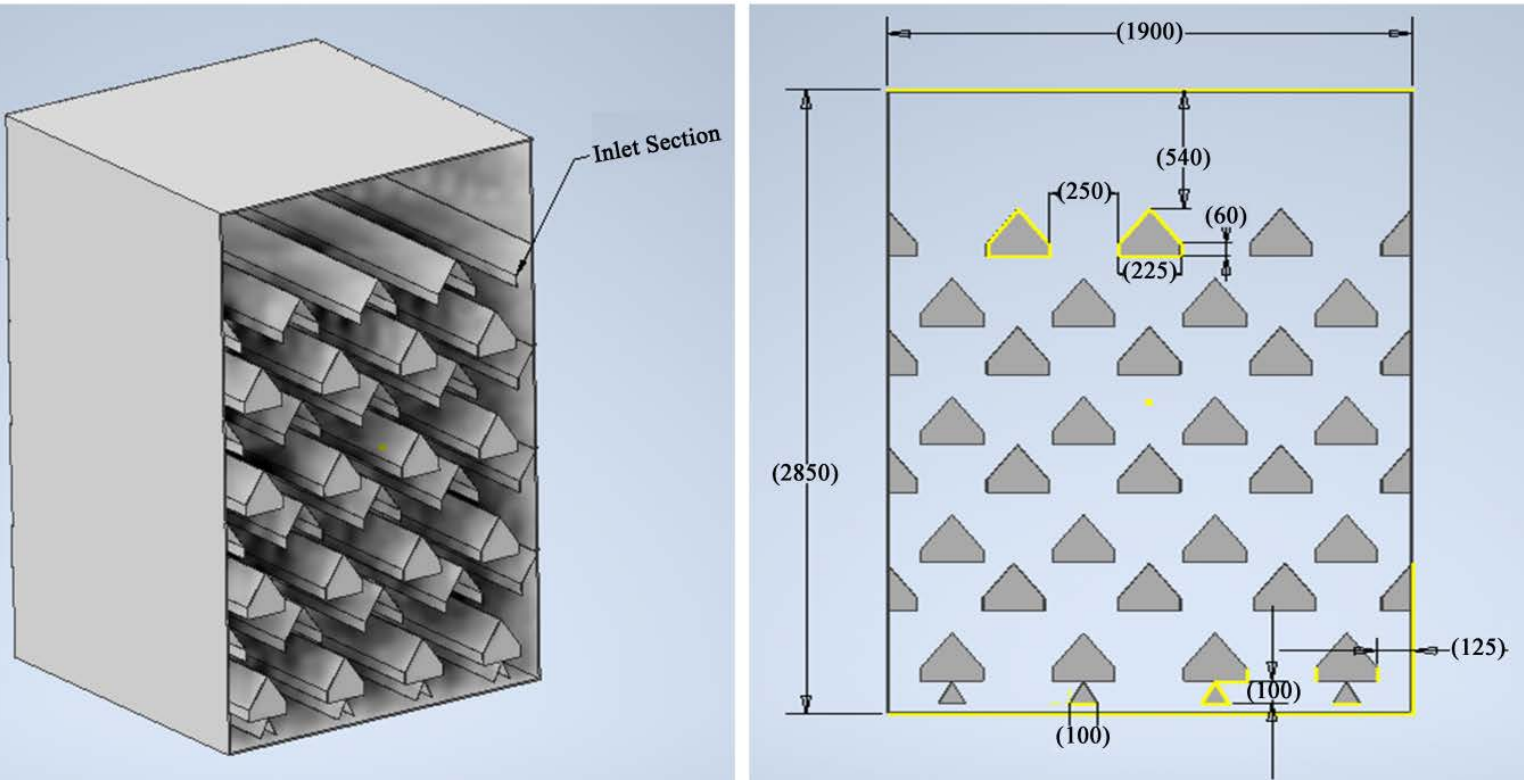

Figure 4. Dimensions of the current dryer in $\mathrm{mm}$.

\subsection{Governing Equations}

Navier-strokes equations were used to solve the fluid flow problem in the ANSYS Fluent. They included three momentum, energy, and mass conservation shown in Equations (1) to (6) [18].

$$
\begin{gathered}
x \text {-momentum, } \quad u=\rho \frac{D u}{D t}=\frac{\delta(\rho u)}{\delta t}+\operatorname{div}(\rho u U)=\frac{\delta p}{\delta x}+\operatorname{div}(\mu \text { gradu })+S_{M x} \\
y \text {-momentum, } \quad v=\rho \frac{D v}{D t}=\frac{\delta(\rho v)}{\delta t}+\operatorname{div}(\rho v U)=\frac{\delta p}{\delta x}+\operatorname{div}(\mu \operatorname{grad} v)+S_{M y}
\end{gathered}
$$




$$
\begin{gathered}
z \text {-momentum, } \quad w=\rho \frac{D w}{D t}=\frac{\delta(\rho w)}{\delta t}+\operatorname{div}(\rho w U)=\frac{\delta p}{\delta x}+\operatorname{div}(\mu \operatorname{grad} w)+S_{M z} \\
\text { Internal Energy, } i=\frac{\delta(\rho i)}{\delta t}+\operatorname{div}(\rho i U)=-p \operatorname{div} U+\operatorname{div}(\operatorname{kgradT})+\varnothing+S_{i} \\
\text { Mass Conservation, } \frac{\delta(\rho \varnothing)}{\delta t}+\operatorname{div}(\rho \varnothing u)=\rho \frac{D \varnothing}{D t}
\end{gathered}
$$

The general transport equation solved through finite volume Computational Fluid Dynamics (CFD) program is;

$$
\frac{\delta(\rho \varnothing)}{\delta t}+\operatorname{div}(\rho \varnothing U)=\operatorname{div}(\gamma \operatorname{grad} \varnothing)+S_{\varnothing}
$$

where, $\rho=$ Density, $U=$ Velocity term, $\gamma=$ Diffusion constant, $S=$ Source term, $\mu=$ Viscous stress constant, $k=$ Grain drying constant, $p=$ Pressure, $\varnothing=$ Viscous dissipation term that describes conservation of mechanical energy to heat [18].

\subsubsection{Meshing and Solution Technique}

Finite volume method (FVM) was used to mesh the fluid domain in ANSYS Fluent. The method was selected as it conserves mass, momentum and energy even on coarse grids. The approach has a speed and memory advantage for source dominated flows, turbulent flows, and large fluid domains [18]. K-omega turbulence model was employed in the simulation for enhanced wall treatment. The energy, momentum, and mass conservation equations were solved using the pressure-based segregated solver. Segregated solution procedure was used as the Mach number was assumed to be small. In this approach, the momentum equations were first solved to determine $\mathrm{u}, \mathrm{v}$, and $\mathrm{w}$ velocities. Continuity (pressure-correction) equations were then solved and the mass flow rate and pressure updated. The energy, turbulence, species, and other scalar equations were solved and then convergence tested. If the solution does not converge, the properties are updated and the solution procedure repeats. The iteration continued until when the solution converged. Hybrid initialization with 50 iterations was used to compute the solution.

\subsubsection{Boundary Conditions}

The boundary conditions were set based on the no-load experimental parameters. The flow inlet temperature and velocity were set at $50^{\circ} \mathrm{C}$ and $1 \mathrm{~m} / \mathrm{s}$ respectively. Pressure outlet boundary condition was used as the flow was assumed to be subsonic during initialization. The outlet was set at zero gauge pressure with backflow direction normal to boundary. Backflow parameters wee essential in case where the fluid flow reverses the direction. The walls were assumed to be stationary and modelled under no-slip shear conditions. The flow conditions and modeling parameters are indicated in Table 1.

\subsection{Grain Dryer Modification}

Given that the hot air was unevenly distributed across the grain buffer section, 
Table 1. ANSYS Fluent modeling parameters.

\begin{tabular}{cc}
\hline Flow conditions & Modeling parameters \\
\hline Inlet & $1 \mathrm{~m} / \mathrm{s}, 50^{\circ} \mathrm{C}$ \\
Outlet & Zero gauge pressure with backflow direction normal to boundary \\
Wall treatment & Stationary, no-slip shear condition \\
Turbulence model & k-Omega \\
\hline
\end{tabular}

Table 2. Sizing parameters.

\begin{tabular}{ccc}
\hline Flow-guide & Length $(\mathrm{mm})$ & Fillet $(\mathrm{mm})$ \\
\hline Compartment 1 & 590 & 110 \\
Compartment 2 & 1130 & 110 \\
Compartment 3 & 1670 & 110 \\
Compartment 4 & 1810 & 500
\end{tabular}

design modifications were conducted to determine its effect on flow distribution. Hot air flow-guides with filleted edges were introduced at the inlet section. The guides ensured that hot air was evenly distributed across the four compartments in the dryer. The filleted edges also enhanced fluid transition to the grain buffer section. A $500 \mathrm{~m}$ fillet reduced turbulence in the fourth compartment. Also, 110 $\mathrm{mm}$ fillets were put in each of the other three flow-guides in compartments 3,2 , and 1 . The sizing criteria were based on the need to equally divide the incoming hot air into the four compartments. Therefore, the flow guides were equally spaced at a distance of $137.5 \mathrm{~mm}$. All the flow-guides began from the base of the first compartment and stretched to the end of the air inlet sections of each compartments. Table 2 indicates the sizing parameters for the improved dryer. Figure 5 shows the modifictions that were incoporated in the dryer to improve hot air flow distribution across the dryer. Figure 5(a) and Figure 5(b) shows the dimensions of the current and improved dryer respectively.

\subsection{Geometry of Fluid Domain in ANSYS Fluent}

The geometry of the fluid domain for the current and improved dryer is shown in Figure 6(a) and Figure 6(b) below, respectively. Figure 7 is the CFD model in the ANSYS Fluent domain.

\subsection{Mesh Sensitivity Test and Convergence Analysis}

Mesh sensitivity was conducted for the current dryer at $100 \mathrm{~mm}, 75 \mathrm{~mm}, 60 \mathrm{~mm}$, and $50 \mathrm{~mm}$. The convergence tolerance reduced with the decrease in mesh size. From $75 \mathrm{~mm}$ mesh size, there was insignificant change in temperature and velocity contours. However, computation time significantly increased as the mesh was reduced from $60 \mathrm{~mm}$ to $50 \mathrm{~mm}$. The increase in computational time is attributed to the rise in the total number of nodes and elements as the mesh size reduced. 


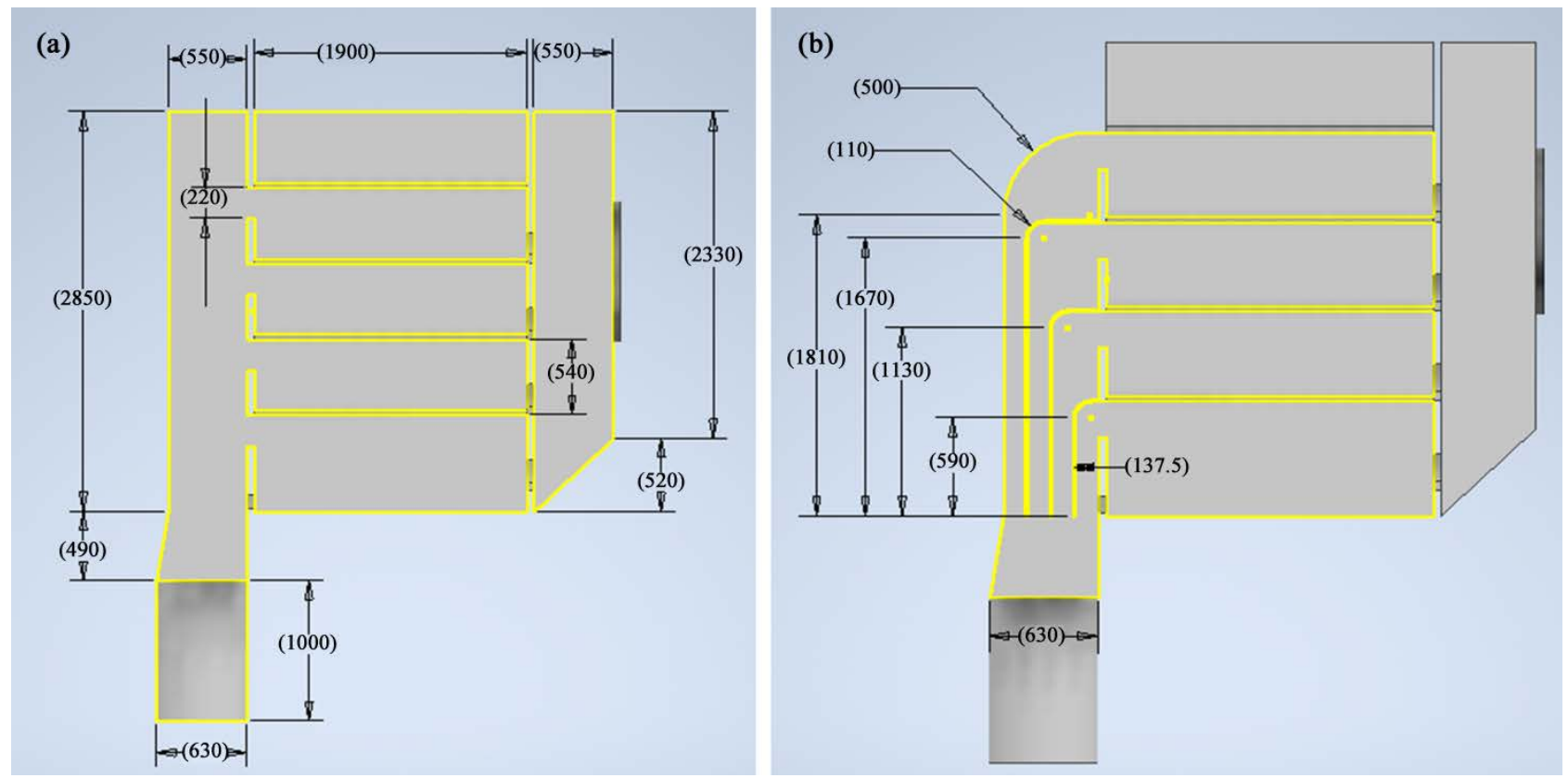

Figure 5. Dimensions of the current and improved dryer. (a) Dimensions of current dryer; (b) Dimensions of improved dryer
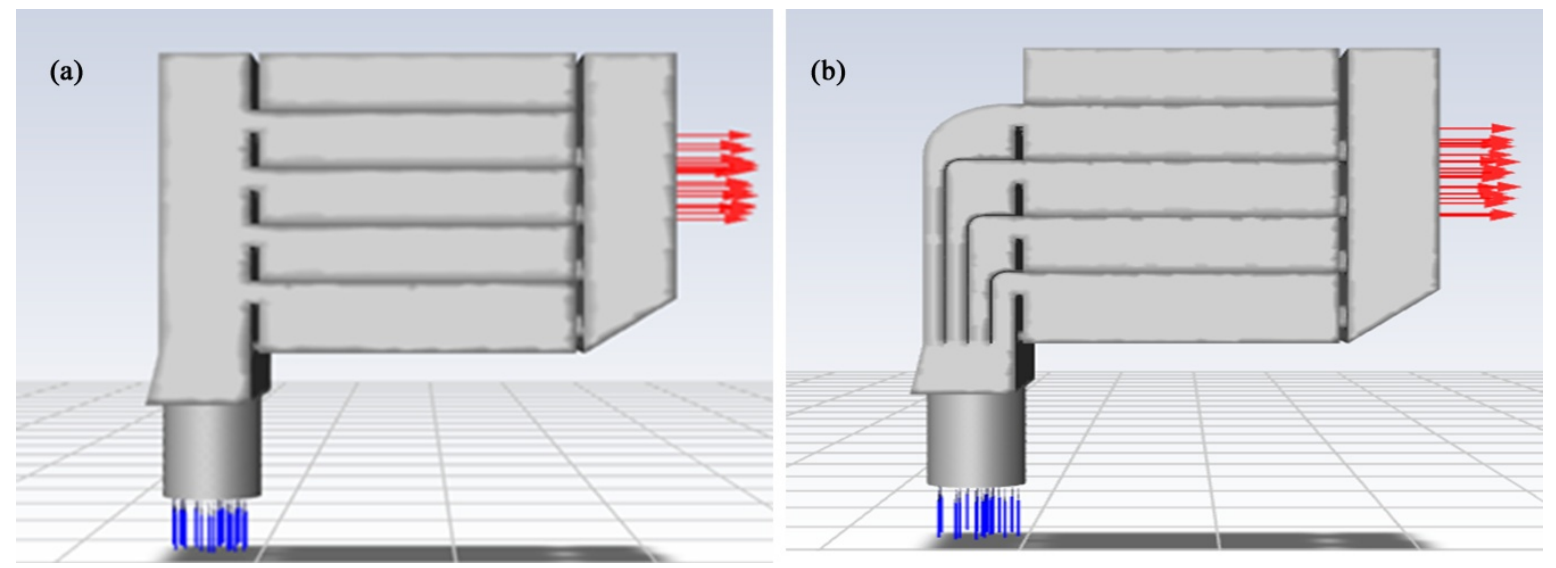

Figure 6. Hot air flow across the dryer. (a) current dryer; (b) Improved dryer.

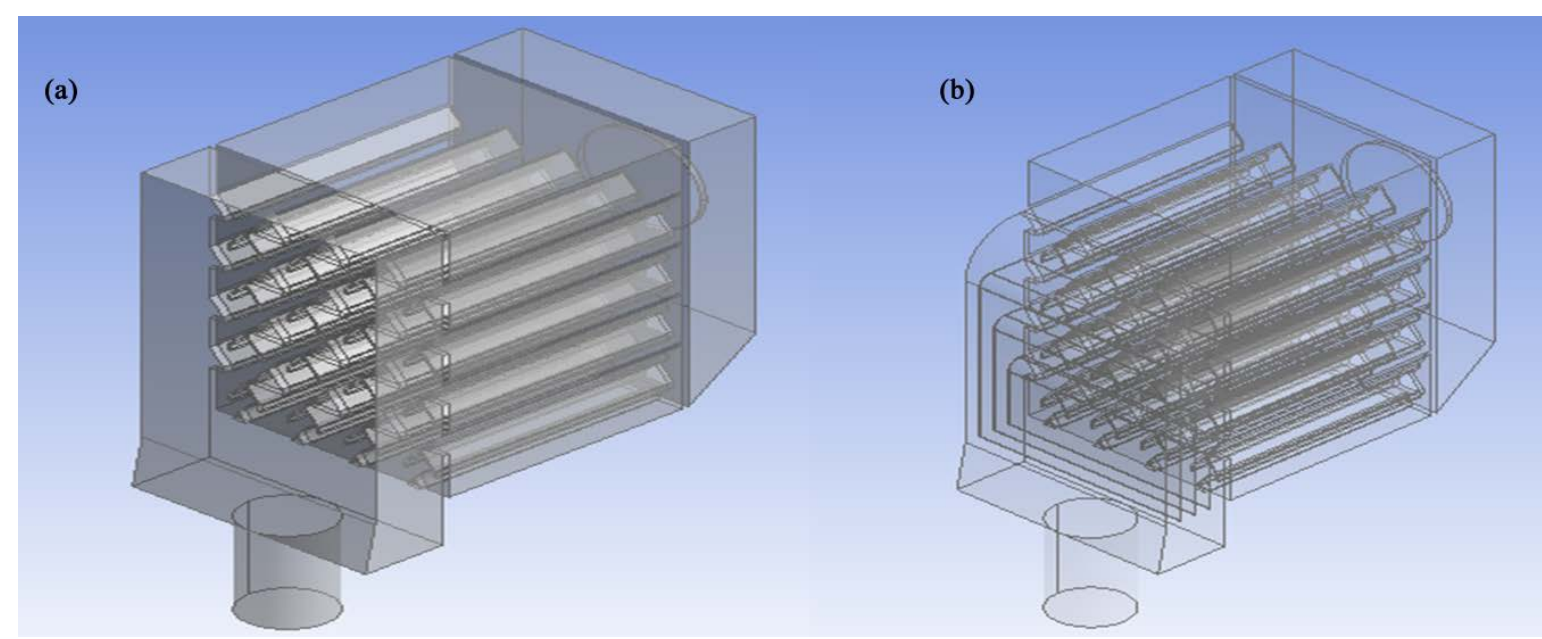

Figure 7. The fluid domain of current and improved dryer. (a) Model of current dryer; (b) Model of improved dryer. 
Figure $8(\mathrm{a})$ is the velocity and temperature contours as the mesh size was reduced from $100 \mathrm{~mm}$ to $75 \mathrm{~mm}$. As the mesh size reduced, the convergence tolerance decreased from $2.899022 \mathrm{e}-04$ to $6.329312 \mathrm{e}-06$. The maximum temperature remained $49.85^{\circ} \mathrm{C}$ even with the reduction in mesh size. However, the minimum temperature reduced from $38.16^{\circ} \mathrm{C}$ to $40.12^{\circ} \mathrm{C}$ while the maximum velocity declined from 1.2 to $1.1 \mathrm{~m} / \mathrm{s}$.

The temperature distribution contours remained relativly uncanged from 75 $\mathrm{mm}$ to $50 \mathrm{~mm}$ Mesh size. There was a slight change in velocity contours from $100 \mathrm{~mm}$ to $75 \mathrm{~mm}$ mesh size. However, the contours remained relatively unchanged as the mesh size reduced from $60 \mathrm{~mm}$ to $50 \mathrm{~mm}$. Given that the temperature and velocity distributions were unchanged between 60 to $50 \mathrm{~mm}$ as shown in Figure 8(b), a further reduction in mesh size was not necessary. Therefore, a mesh size of $50 \mathrm{~mm}$ was considered for the simulation model.

As the mesh size reduced from $100 \mathrm{~mm}$ to $75 \mathrm{~mm}$, the maximum velocity slightl increased from 1.36 to $1.37 \mathrm{~m} / \mathrm{s}$ as shown in Figure 9(a). The maximum temperature remained unchanged at 49.85 .

The temperature and velocity contours were gradually refined with the reduction in mesh from $100 \mathrm{~mm}$ to $50 \mathrm{~mm}$. The convergence tolerance also reduced with the decrease in mesh size. However, the temperature and velocity contours did not significantly change as the mesh was reduced from $60 \mathrm{~mm}$ to $50 \mathrm{~mm}$, Figure 9(b). Therefore, a mesh size of $50 \mathrm{~mm}$ was also considered for the improved model.

\subsection{Mesh Sensitivity Results for the Improved Model}

Velocity magnitudes were sampled at the inlet, center, and outlet sections of the grain buffer section for $100 \mathrm{~mm}, 75 \mathrm{~mm}, 60 \mathrm{~mm}$, and $50 \mathrm{~mm}$ mesh sizes. The results displayed in Table 3 and Figures 10(a)-(d), indicates that the velocity distribution did not significantly change as the mesh was reduced from $75 \mathrm{~mm}$ to $60 \mathrm{~mm}$ and then $50 \mathrm{~mm}$.

Based on the results, the maximum velocity deviation from $75 \mathrm{~mm}$ to $50 \mathrm{~mm}$ mesh was $0.05 \mathrm{~m} / \mathrm{s}$. The velocity distribution for $75 \mathrm{~mm}, 60 \mathrm{~mm}$, and $50 \mathrm{~mm}$ were nearly the same. However, the time taken to solve the energy equations significantly increased with further reduction in mesh size. Therefore, a mesh size of $50 \mathrm{~mm}$ was considered for the CFD model.

\section{Results and Discussion}

\subsection{Experimental Results}

The experimental results confirm the existence of uneven grain drying in the current geothermal dryer. Grains near the hot air inlet dry at a considerably higher rate that those near the exhaust section. Further, grains in the first compartment near the hot air inlet dried at a faster rate than those in the second and third compartments. The temperature at the inlet section ranged between $51^{\circ} \mathrm{C}$ and $50^{\circ} \mathrm{C}$ and $44^{\circ} \mathrm{C}$ to $41^{\circ} \mathrm{C}$ in the exhaust section. Table 4 shows the 
(a)

\section{Convergence}
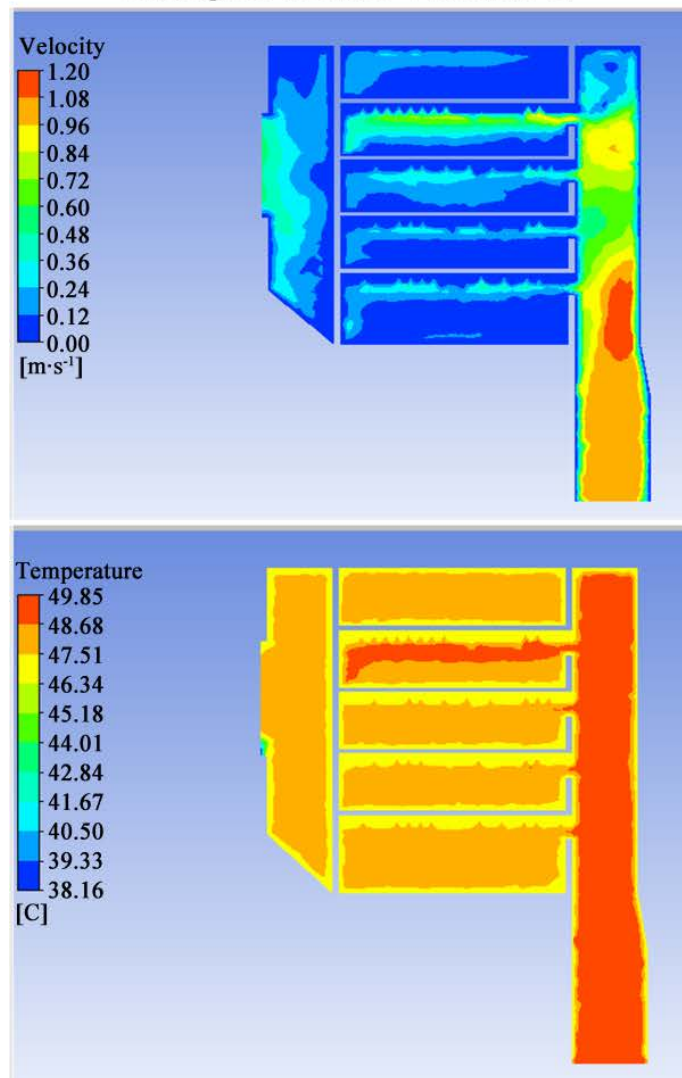

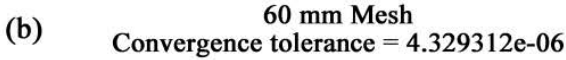

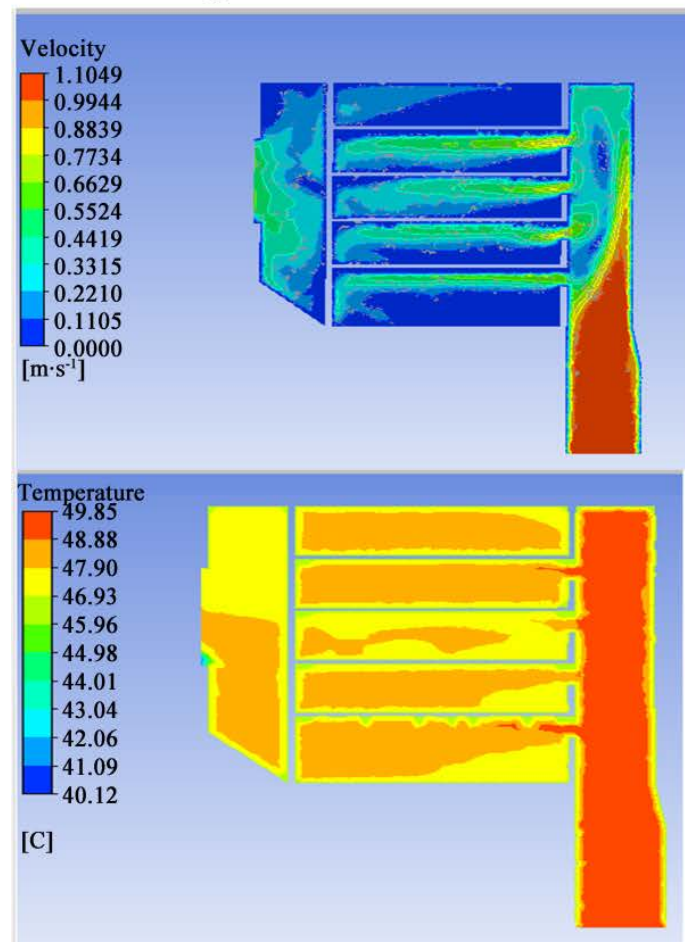

$75 \mathrm{~mm}$ Mesh

Convergence tolerance $=6.329312 \mathrm{e}-06$
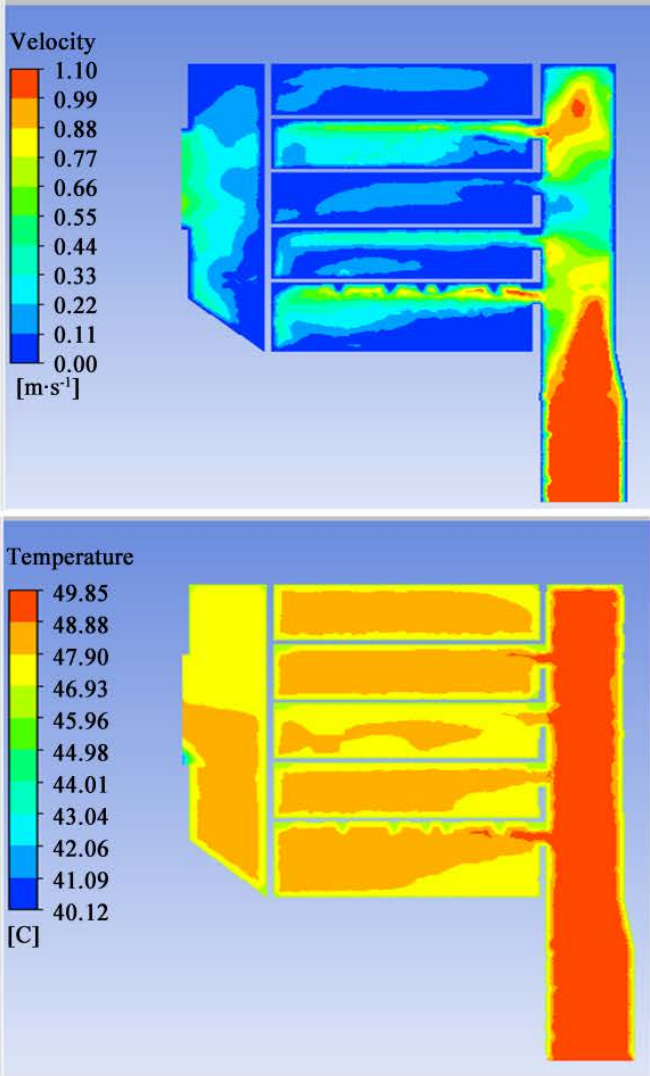

$50 \mathrm{~mm}$ Mesh

Convergence tolerance $=3.051124 \mathrm{e}-06$
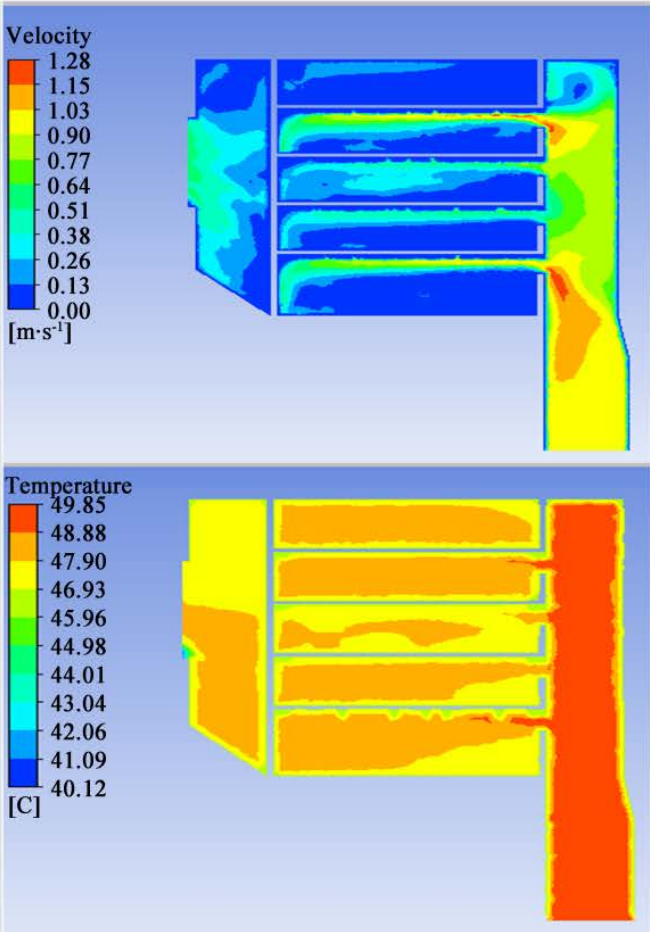

Figure 8. (a) Velocity and temeprature contours for 100 and $75 \mathrm{~mm}$ Mesh of the current dryer; (b) Velocity and temeprature contours for 60 and $50 \mathrm{~mm}$ Mesh of the current dryer. 
(a) $100 \mathrm{~mm} \mathrm{Mesh}$ Convergence tolerance $=9.075105 \mathrm{e}-06$
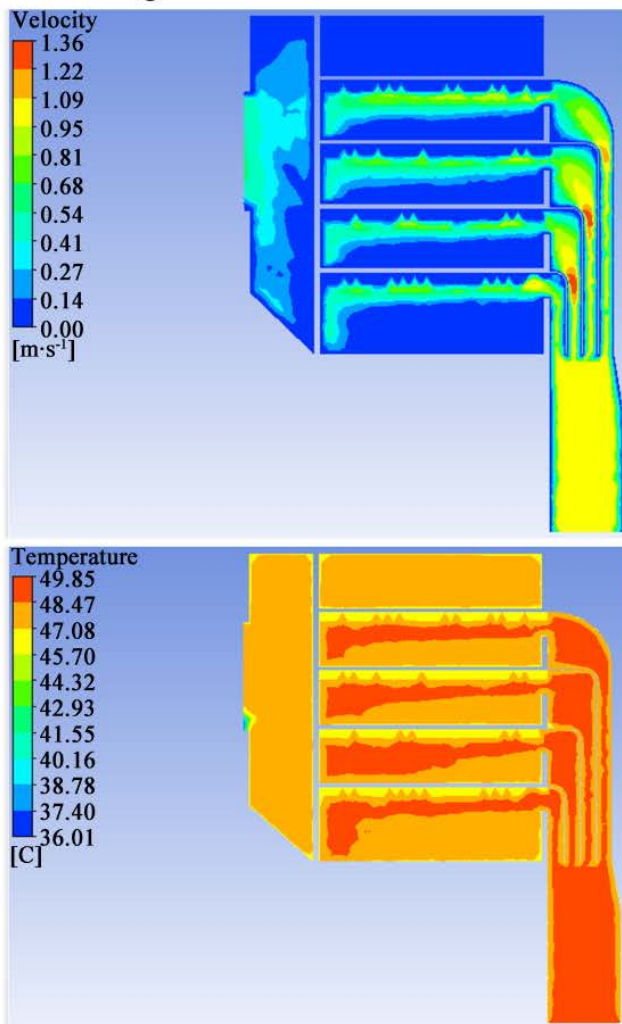

(b) $60 \mathrm{~mm}$ Mesh

Convergence tolerance $=3.940452 \mathrm{e}-06$
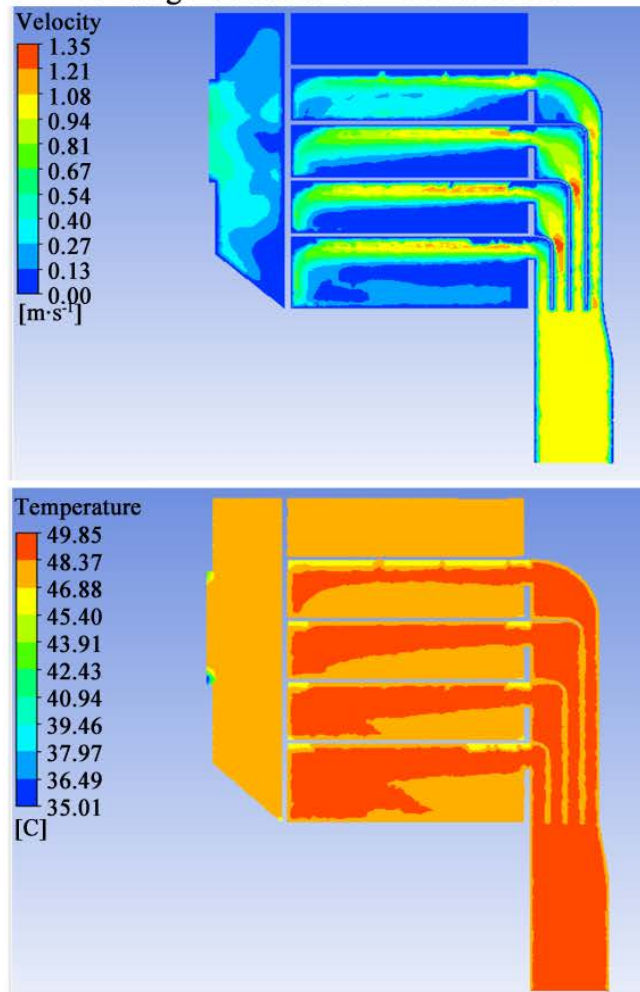

$75 \mathrm{~mm}$ Mesh

Convergence tolerance $=4.374388 \mathrm{e}-06$

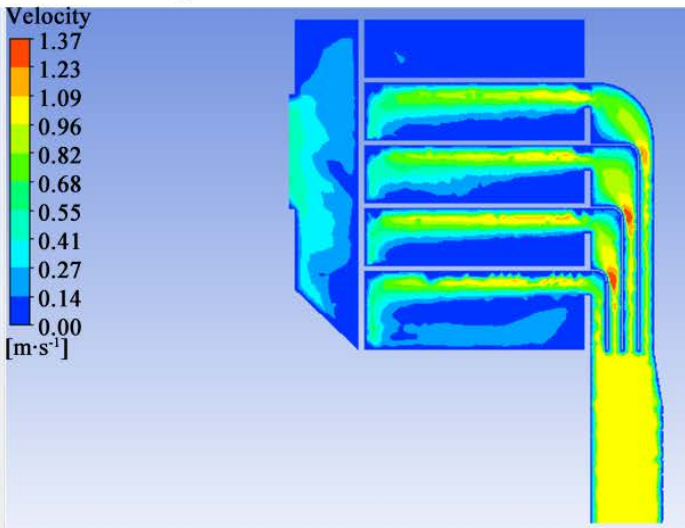

Temperature
\begin{tabular}{|l|l}
\hline 49.85 \\
-48.55 \\
-47.24 \\
45.94 \\
44.63 \\
43.32 \\
-42.02 \\
40.71 \\
39.41 \\
38.10 \\
36.80
\end{tabular}

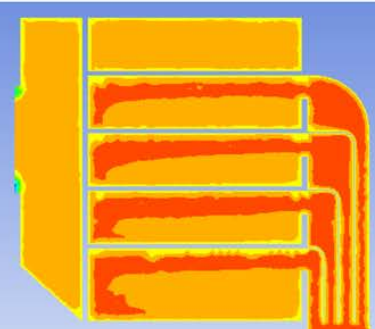

$50 \mathrm{~mm}$ Mesh

Convergence tolerance $=2.949699 \mathrm{e}-06$
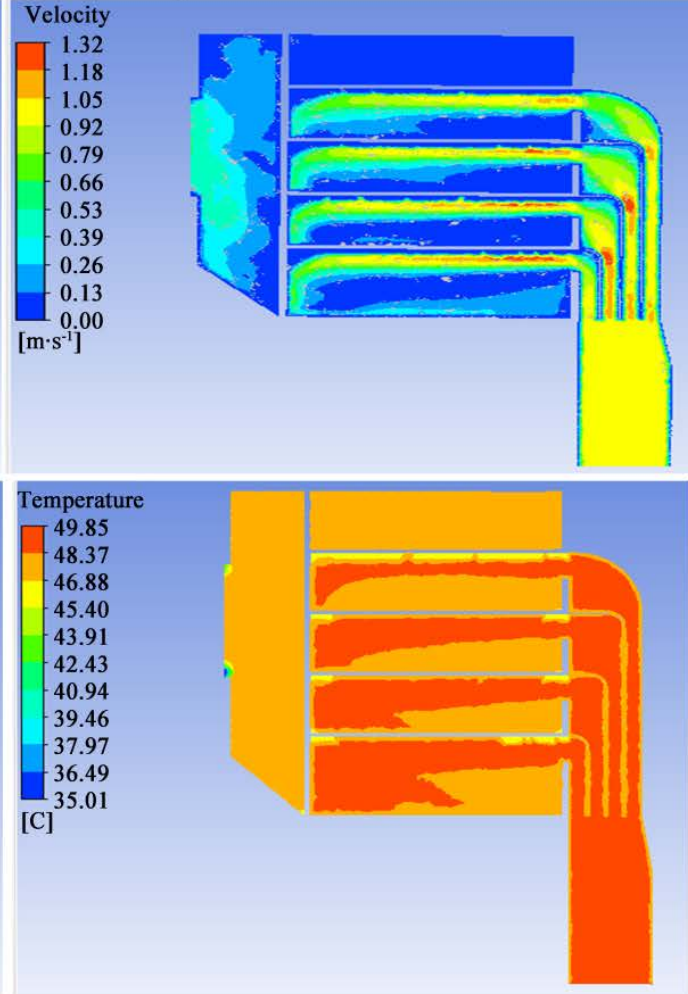

Figure 9. (a) Velocity and temeprature contours for 100 and $75 \mathrm{~mm}$ Mesh of the improved dryer; (b) Velocity and temeprature contours for 60 and $50 \mathrm{~mm}$ Mesh of the improved dryer. 
Table 3. Velocity magnitudes at different mesh sizes.

\begin{tabular}{ccccccc}
\hline \multirow{2}{*}{ Compartment } & \multicolumn{3}{c}{$100 \mathrm{~mm}$} & & \multicolumn{3}{c}{$75 \mathrm{~mm}$} \\
\cline { 2 - 7 } & inlet & center & outlet & inlet & center & outlet \\
\hline 1 & 0.92 & 0.58 & 0.49 & 0.97 & 1.00 & 0.59 \\
2 & 0.55 & 0.69 & 0.49 & 1.10 & 1.04 & 0.59 \\
3 & 0.72 & 0.62 & 0.45 & 1.06 & 0.99 & 0.51 \\
4 & 0.88 & 0.83 & 0.47 & 1.05 & 0.89 & 0.47 \\
\hline \multirow{2}{*}{ Compartment } & & & & & & \\
\cline { 2 - 7 } 1 & inlet & center & outlet & inlet & center & outlet \\
\hline 2 & 0.99 & 1.05 & 0.62 & 1.01 & 1.06 & 0.63 \\
3 & 1.10 & 1.03 & 0.61 & 1.08 & 1.03 & 0.61 \\
4 & 1.06 & 0.95 & 0.51 & 1.09 & 0.96 & 0.52 \\
\hline & 1.07 & 0.91 & 0.51 & 1.07 & 0.94 & 0.52 \\
\hline
\end{tabular}

Table 4. Experiment 1: Grain drying.

\begin{tabular}{|c|c|c|c|c|c|c|c|c|c|c|}
\hline \multirow{3}{*}{ Time } & \multicolumn{2}{|c|}{ Temperature } & \multicolumn{2}{|c|}{$\begin{array}{c}\text { Relative } \\
\text { Humidity RH (\%) }\end{array}$} & \multicolumn{6}{|c|}{ Moisture Content (\%), in wet basis } \\
\hline & \multirow[t]{2}{*}{ Inlet } & \multirow[t]{2}{*}{ Exhaust } & \multirow[t]{2}{*}{ Inlet } & \multirow[t]{2}{*}{ Exhaust } & \multicolumn{3}{|c|}{$\begin{array}{l}\text { Inlet } \\
\text { Compartments }\end{array}$} & \multicolumn{3}{|c|}{$\begin{array}{c}\text { Outlet } \\
\text { Compartments }\end{array}$} \\
\hline & & & & & 1 & 2 & 3 & 1 & 2 & 3 \\
\hline $1: 40$ & 50.1 & 44.0 & 20.0 & 27.2 & 21.1 & 21.1 & 21.1 & 21.1 & 21.1 & 21.1 \\
\hline $2: 00$ & 50.5 & 43.0 & 20.0 & 27.0 & 18.0 & 18.7 & 20.0 & 20.0 & 20.5 & 20.9 \\
\hline $2: 20$ & 50.3 & 41.0 & 20.0 & 30.0 & 17.5 & 18.4 & 19.8 & 19.5 & 20.3 & 20.6 \\
\hline $2: 40$ & 50.0 & 41.3 & 20.0 & 32.0 & 17.0 & 17.6 & 19.3 & 19.1 & 19.6 & 20.3 \\
\hline $3: 00$ & 50.0 & 41.1 & 20.1 & 32.0 & 16.4 & 18.0 & 20.3 & 18.5 & 19.4 & 20.3 \\
\hline $3: 20$ & 50.9 & 41.0 & 20.0 & 30.0 & 16.0 & 17.0 & 17.5 & 18.3 & 19.1 & 19.8 \\
\hline $3: 40$ & 51.0 & 41.0 & 20.0 & 30.0 & 15.6 & 17.0 & 17.5 & 17.8 & 19.0 & 19.5 \\
\hline $3: 43$ & \multicolumn{10}{|c|}{$\begin{array}{l}\text { Grain Recirculation (Elevator Motor on), circulating mixed grains } \\
\text { sampled as they leave the dryer }\end{array}$} \\
\hline 4:00 & 51.0 & 41.2 & 20.0 & 30.0 & \multicolumn{6}{|c|}{16.0} \\
\hline $4: 20$ & 50.8 & 41.0 & 20.0 & 30.0 & \multicolumn{6}{|c|}{15.9} \\
\hline $4: 40$ & 50.0 & 41.1 & 20.0 & 30.0 & \multicolumn{6}{|c|}{15.6} \\
\hline 5:00 & 50.0 & 41.1 & 20.1 & 30.0 & \multicolumn{6}{|c|}{15.5} \\
\hline $5: 20$ & 50.0 & 41.0 & 20.0 & 30.0 & \multicolumn{6}{|c|}{15.3} \\
\hline $5: 40$ & 50.0 & 41.0 & 20.0 & 30.0 & \multicolumn{6}{|c|}{16.5} \\
\hline $6: 00$ & 50.0 & 41.0 & 20.0 & 30.0 & \multicolumn{6}{|c|}{16.5} \\
\hline $6: 10$ & 50.0 & 41.0 & 20.3 & 30.0 & \multicolumn{6}{|c|}{16.5} \\
\hline
\end{tabular}



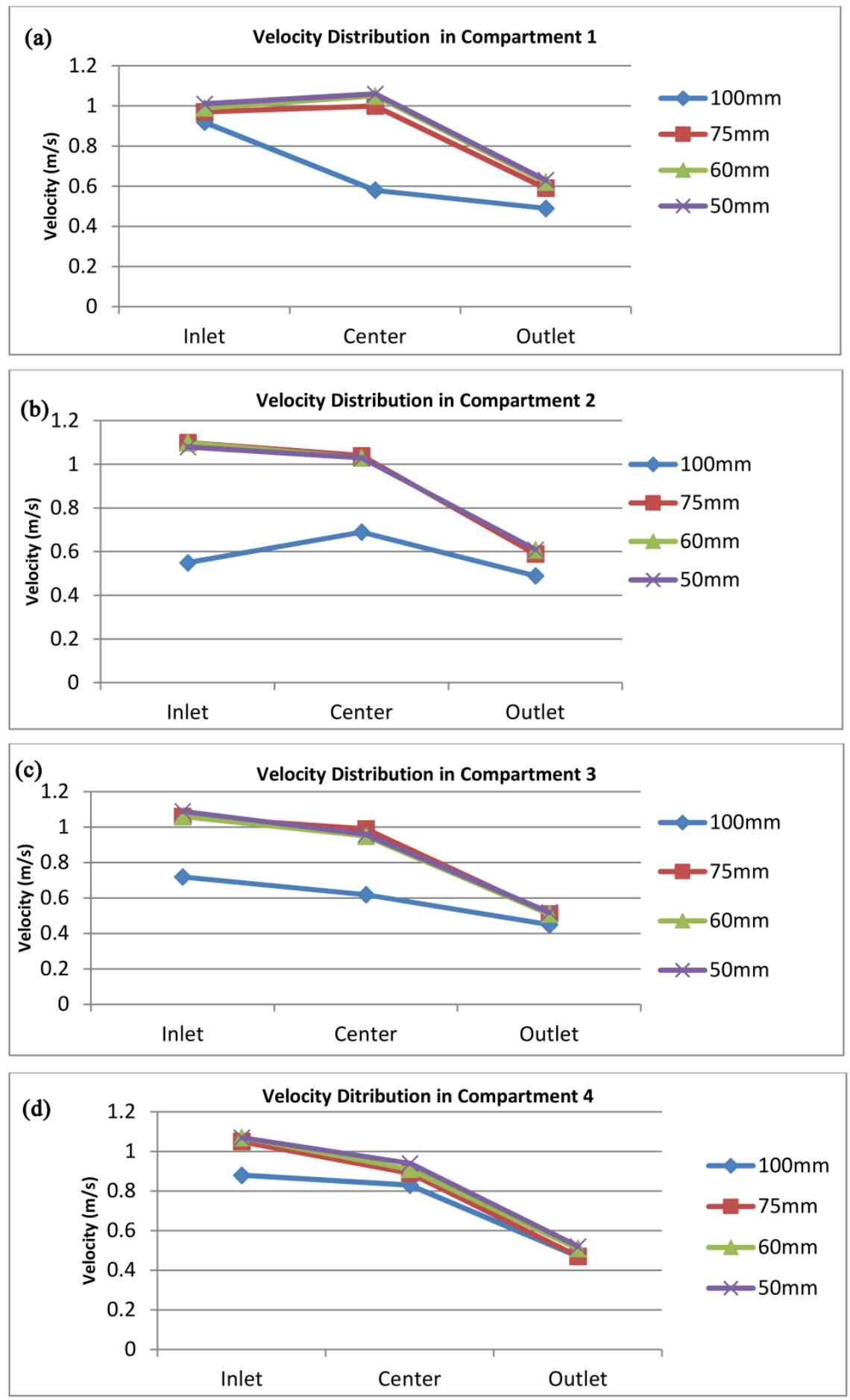

Figure 10. Velocity distribution for different mesh size in the 4 compartments. (a) Velocity distribution for different mesh size in compartment 1; (b) Velocity distribution for different mesh size in compartment 2; (c) Velocity distribution for different mesh size in compartment 3; (d) Velocity distribution for different mesh size in compartment 4

temperature distribution along with moisture content in the three compartments occupied with grains.

After two hours of drying, the moisture content in compartment 1 near the 
inlet section was $15.6 \%$ and $17.8 \%$, wet basis in the exhaust section. Wettest grains had a moisture content of $19.5 \%$ and were in the third compartment, near the exhaust section. Grain recirculation was initiated to ensure uniform drying. However, the rate of moisture reduction during recirculation was considerably low. After 2 hours 30 minutes of simultaneous grain drying and recirculation, the moisture content reduced to $16.5 \%$. Therefore, it took 4 hours 30 minutes to reduce the grain moisture content from $21.1 \%$ to $16.5 \%$ as shown in Figure 11 below.

Based on the data, temperature distribution varies slightly across the dryer. The hottest sections are located near the hot air inlet. Conversely, the sections near the exhaust have the lowest temperature. The drop in temperature is attributed to losses along the walls of the dryer.

The no-load experiment affirms that the air flow is statistically steady as the average flow features do not vary with time. Table 5 shows recorded temperature distribution at different points of the dryer. The temperature magnitudes at the inlet, exhaust, and 4 compartments did not significantly change with time. The temperature in the inlet compartments is considerably higher than that in the exhaust section.

\subsection{Model Validation}

The model was validated using no-load experimental results obtained from the current geothermal grain dryer in Menengai. The temperature distribution at the

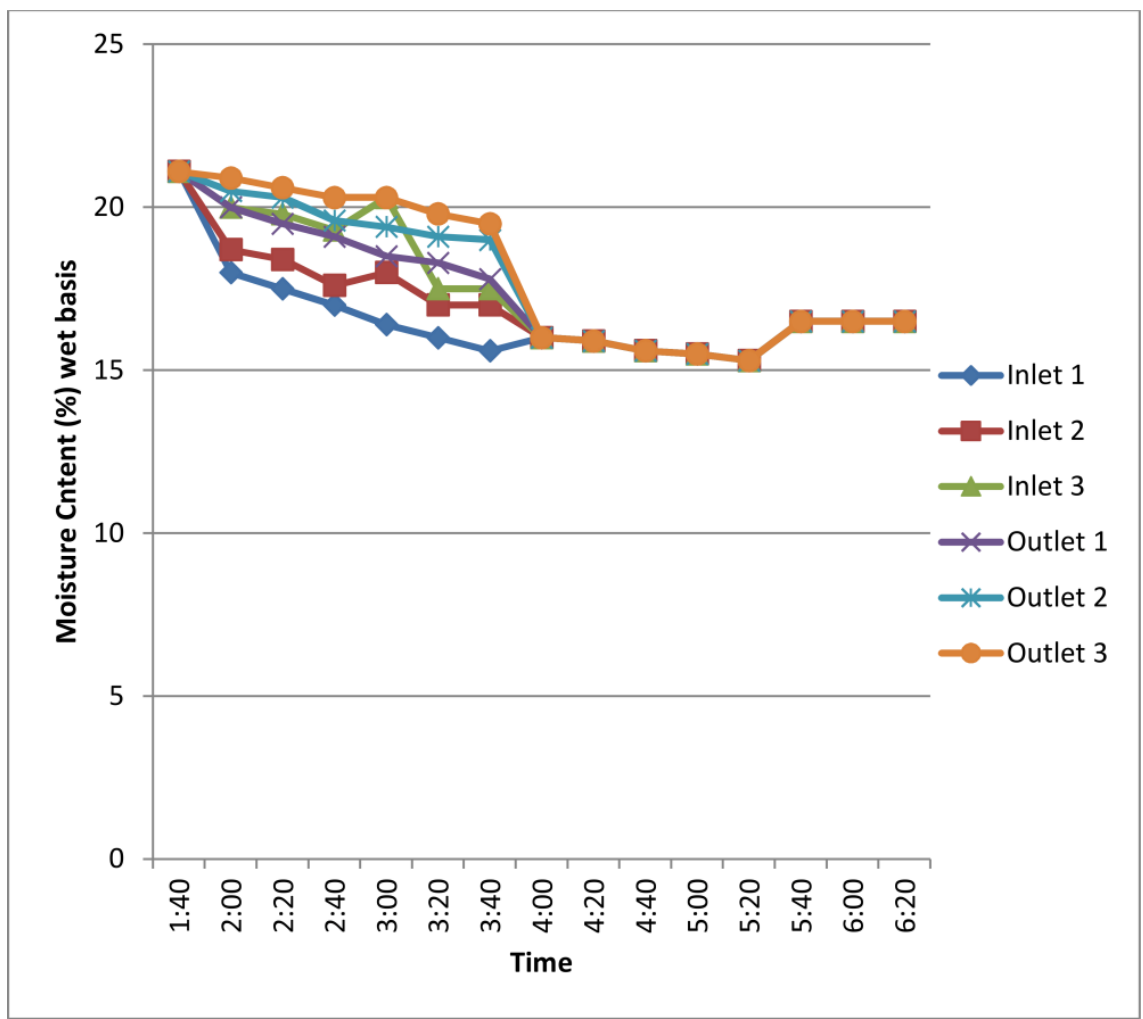

Figure 11. Grain drying curves for different compartments. 
inlet and outlet sections obtained from experiments was compared with the Ansys simulation results. Hot air entered the dryer at $50^{\circ} \mathrm{C}$, and at a velocity of 1 $\mathrm{m} / \mathrm{s}$. The temperatures at the inlet and exhaust sections of the compartments were taken at steady state conditions. The results are shown in Table 6.

Figure 12 compares the experimental temperature distribution with that of the simulation model. The average percentage error obtained by comparing the experiment with simulation results is -0.272 . The small percentage error shows that the Ansys simulation model is a good representation of the geothermal grain dryer. The obtained temperature distribution can be corrected by adding 0.272 to the displayed values.

\subsection{Simulation Results}

\subsubsection{Simulation Results at Operating Inlet Conditions $\left(\mathrm{T}=323 \mathrm{~K}\left(50^{\circ} \mathrm{C}\right)\right.$, $\mathrm{V}=1 \mathrm{~m} / \mathrm{s}$ )}

The contours below show velocity, temperature, and turbulence kinetic energy for the current and improved grain dryer. Velocity sensitivity was conducted at $1.25,1$, and $0.75 \mathrm{~m} / \mathrm{s}$. Studies have shown that optimal grain drying takes place

Table 5. Experiment 2: No-load experiment results.

\begin{tabular}{cccccccc}
\hline Time (Minutes) & $\mathbf{0}$ & $\mathbf{1 0}$ & $\mathbf{2 0}$ & $\mathbf{3 0}$ & $\mathbf{4 0}$ & $\mathbf{5 0}$ & Average \\
\hline Inlet & 26.5 & 50.0 & 50.0 & 50.0 & 50.1 & 50.0 & 50.0 \\
Compartment 1, Inlet & 26.5 & 49.5 & 49.6 & 49.6 & 49.5 & 49.7 & 49.6 \\
Compartment 2, Inlet & 26.5 & 49.0 & 49.0 & 49.1 & 49.1 & 49.1 & 49.1 \\
Compartment 3, Inlet & 26.5 & 49.2 & 49.2 & 49.2 & 49.2 & 29.2 & 49.2 \\
Compartment 4, Inlet & 26.5 & 49.7 & 49.7 & 49.5 & 49.6 & 49.5 & 49.6 \\
Exhaust Section, upper end & 26.5 & 48.0 & 48.1 & 48.0 & 48.0 & 48.0 & 48.0 \\
Exhaust section, lower end & 26.5 & 48.3 & 48.3 & 48.4 & 48.4 & 48.4 & 48.4 \\
\hline
\end{tabular}

Table 6. Validation data.

\begin{tabular}{|c|c|c|c|c|c|}
\hline & \multicolumn{3}{|c|}{ Temperature results } & \multirow{4}{*}{$\begin{array}{c}\% \\
\text { Error }\end{array}$} & \multirow{4}{*}{$\begin{array}{l}\text { Average } \\
\% \text { error }\end{array}$} \\
\hline & Ansys & s Model & Experiment & & \\
\hline & \multicolumn{3}{|c|}{ Temperature Temperature Temperature } & & \\
\hline & in $\mathrm{K}$ & in ${ }^{\circ} \mathrm{C}$ & in ${ }^{\circ} \mathrm{C}$ & & \\
\hline Inlet & 323.0 & 50 & 50.0 & 0 & 0 \\
\hline Compartment 1 , Inlet & 322.5 & 49.5 & 49.6 & -0.202 & \\
\hline Compartment 2 , Inlet & 321.9 & 48.9 & 49.1 & -0.407 & \\
\hline Compartment 3 , Inlet & 322.0 & 49 & 49.2 & -0.407 & ברג \\
\hline Compartment 4 , Inlet & 322.5 & 49.5 & 49.6 & -0.202 & \\
\hline Exhaust Section, upper end & 320.9 & 47.9 & 48.0 & -0.208 & \\
\hline Exhaust section, lower end & 321.3 & 48.3 & 48.4 & -0.207 & \\
\hline
\end{tabular}




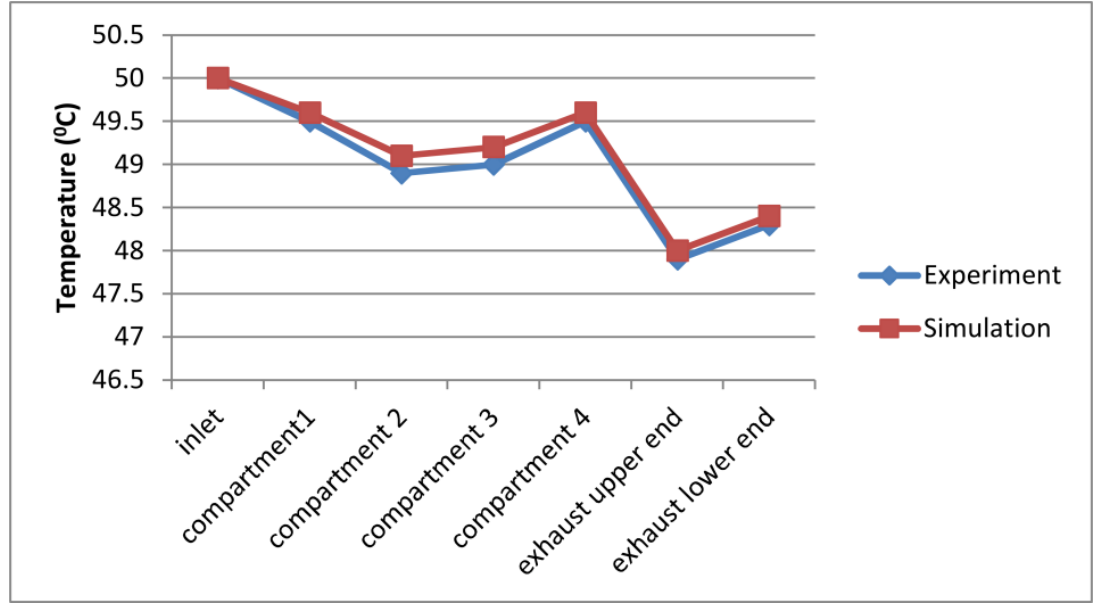

Figure 12. A graph of experiment versus simulation results.

at a temperature of between $50^{\circ} \mathrm{C}$ and $60^{\circ} \mathrm{C}$ [6]. Therefore, temperature sensitivity was performed at $55^{\circ} \mathrm{C}, 50^{\circ} \mathrm{C}$ and $45^{\circ} \mathrm{C}$. The mesh sensitivity was tested at $100,75,60$, and $50 \mathrm{~mm}$ for both current and improved dryer.

The Ansys simulations show that hot air is unevenly distributed across the current geothermal grain dryer. The velocity, temperature, and turbulence kinetic energy were higher in the inlet section compared to the exhaust end as shown in Figure 13(a), Figure 13(c), Figure 13(e), and Figure 13(g). Therefore, grains near the hot air inlet dry at a faster rate than those in the outlet end. The velocity and temperature contours are fully distributed across the $1^{\text {st }}$ and $4^{\text {th }}$ compartments as shown in Figure 13(a) and Figure 13(e). However, the hot air flow is not fully distributed in the $2^{\text {nd }}$ and $3^{\text {rd }}$ compartments. Thus, grains in the first compartment dry at a relatively faster rate than those in the $2^{\text {nd }}$ and $3^{\text {rd }}$ compartments.

The improved dryer had better flow distribution across the dryer. The velocity, temperature, and turbulence kinetic energy were evenly distributed as shown in Figure 13(b), Figure 13(d), Figure 13(f), and Figure 13(h) to ensure uniform grain drying. Introduction of flow guides at the inlet section ensured that hot air is pumped into each compartment at relatively same velocity. The filleted edges also minimized turbulence kinetic energy at the inlet section. Further, the hot air velocity and temperature magnitudes across all the four compartments increased. Consequently, introducing the filleted flow-guides at the inlet could potentially solve the problem of uneven grain drying and also increase drying rate.

At an inlet temperature of $50^{\circ} \mathrm{C}$ and velocity of $1 \mathrm{~m} / \mathrm{s}$, the simulation results show that the filleted flow guides improve hot air distribution through the grain buffer. Temperature and velocity contours are uniformly distributed from the inlet to the outlet sections of the improved dryer. The turbulence kinetic energy is also uniformly distributed in the improved dryer.

\subsubsection{Results When Inlet Temperature Is Increased to $328 \mathrm{~K}\left(55^{\circ} \mathrm{C}\right)$ and Velocity Maintained at $1 \mathrm{~m} / \mathrm{s}$}

The results indicate significant improvements in velocity, temperature, and 

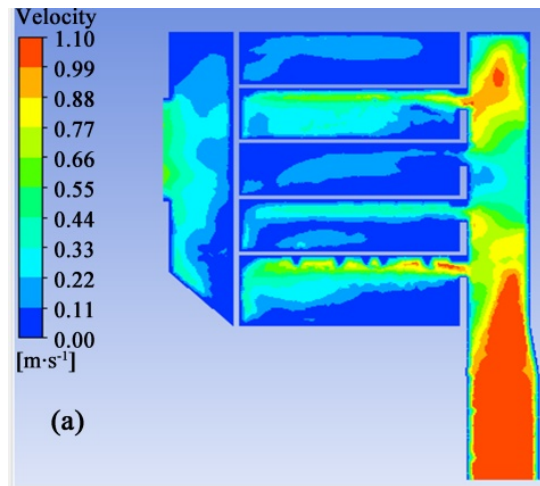

(a)

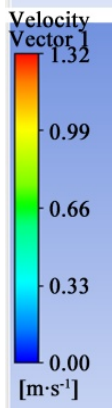

(c)

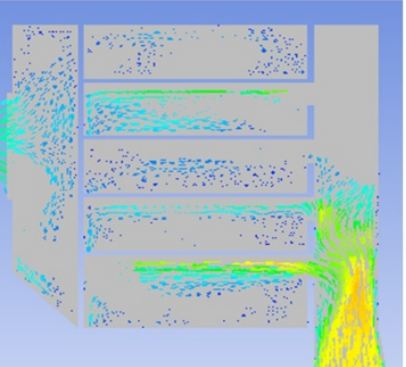

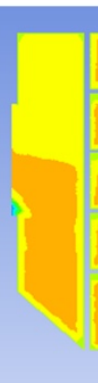

40.12

(e)

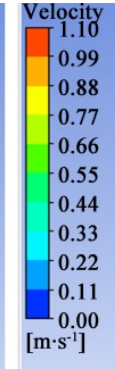

(b)
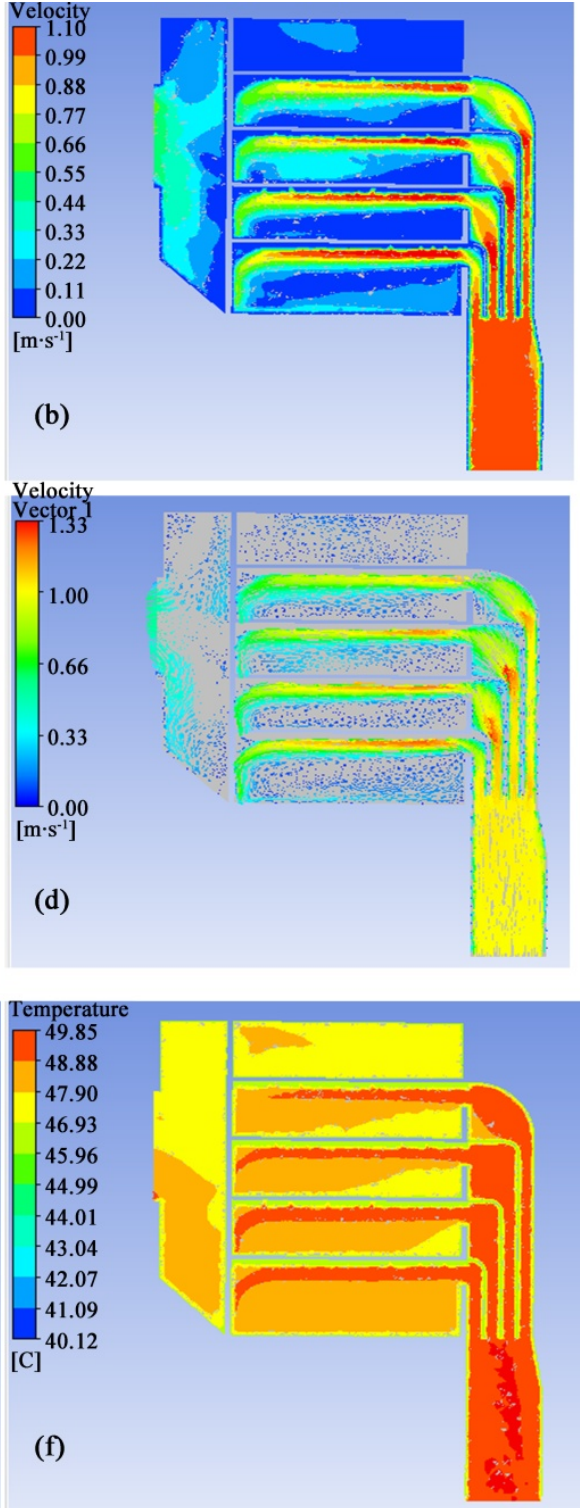

(f)
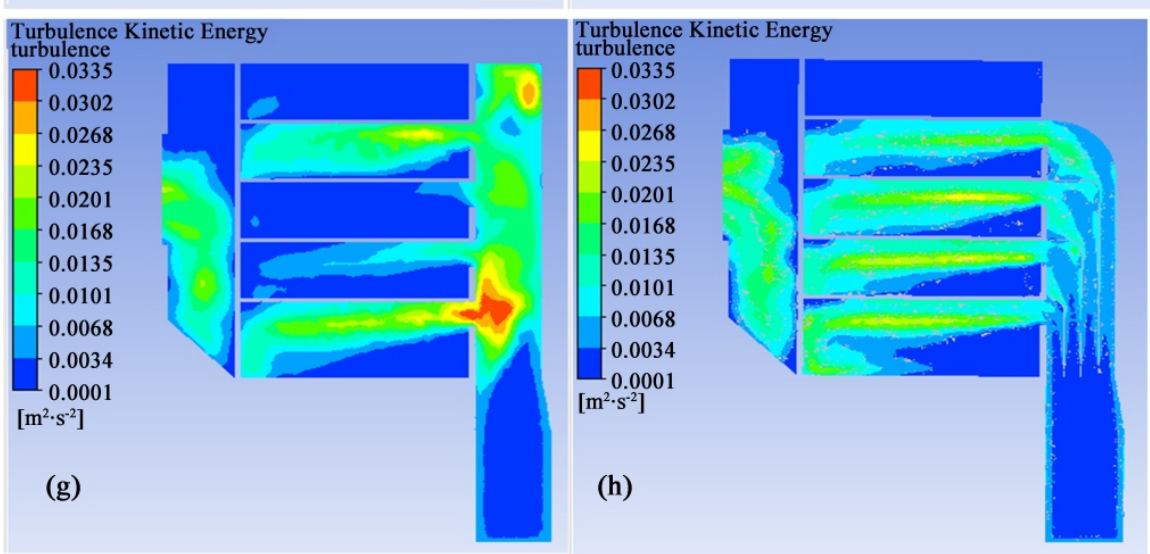

Figure 13. (a) Velocity countours for current dryer; (b) Velocity countours for improved dryer; (c) Velocity vectors for current dryer; (d) Velocity vectors for improved dryer; (e) Temperature countours for current dryer; (f) Temperature countours for improved dryer; (g) Turbulence countours for current dryer; (h) Turbulence countours for improved dryer. 
turbulence kinetic energy distribution when filleted flow guides are introduced in the dryer. The temperature is evenly distributed across the four compartments in the improved dryer as shown in Figure 14(f). In the current dryer, temperature and turbulence kinetic energy in the inlet section is higher than in the outlet end, Figure 14(e) and Figure 14(g). The filleted flow-guides in improved dryer ensure equal amount of hot air is distributed in the compartments. Consequently, the velocity, temperature, and turbulence kinetic energy are evenly distributed in the improved dryer as shown in Figure 14(a), Figure 14(c), Figure 14(f), and Figure 14(h).

\subsubsection{Results When Inlet Temperature Is Reduced to $318 \mathrm{~K}\left(45^{\circ} \mathrm{C}\right)$ and Velocity Maintained at $1 \mathrm{~m} / \mathrm{s}$}

The current dryer still displayed uneven temperature, velocity, and turbulence kinetic energy distribution as shown in Figure 15(a), Figure 15(c), Figure 15(e), and Figure 15(g). However, hot air distribution is uniform for the improved dryer. The magnitude of velocity, temperature and turbulence kinetic energy distribution increases with the incorporation of filleted flow guides at the inlet section as shown in Figure 15(b), Figure 15(d), Figure 15(f), and Figure 15(h). Even when the temperature is reduced to $45^{\circ} \mathrm{C}$, turbulence and kinetic energy distribution are not significantly affected. The filleted flow guides ensure equal amount of hot air is distributed in the four compartments. However, temperature is unevenly distributed even for the improved dryer. Higher temperatures are recorded near the inlet section than in the outlet end.

\subsubsection{Results When Inlet Temperature Is Maintained at $50^{\circ} \mathrm{C}(323 \mathrm{~K})$ and Velocity Increased to $1.25 \mathrm{~m} / \mathrm{s}$}

The velocity, temperature, and turbulence kinetic energy is evenly distributed through the grain buffer for the improved dryer as shown in Figure 16(b), Figure 16(d), Figure 16(f), and Figure 16(h). However, his flow parameters were unevenly distributed in the current dryer as shown in Figure 16(a), Figure $16(\mathrm{c})$, Figure 16(e), Figure 16(g). As velocity increases, temperature distribution across the compartments in the improved model becomes more even. A higher drying rate can be achieved with the increase in velocity.

\subsubsection{Results When Inlet Temperature Is Maintained at $50^{\circ} \mathrm{C}(323 \mathrm{~K})$ and Velocity Reduced to $0.75 \mathrm{~m} / \mathrm{s}$}

The improved grain dryer has relatively uniform temperature, velocity, and turbulence kinetic energy distribution across the grain buffer section as shown in Figure 17(b), Figure 17(d), Figure 17(f), and Figure 17(h). As the velocity reduced from 1 to $0.75 \mathrm{~m} / \mathrm{s}$, temperature distribution remains relatively even. However, the temperature magnitudes in the exhaust end increases with the increase in velocity. In Figure 17(a), velocity, magnitudes are high in compartments 1 and 4 . However, compartments 2 and 3 have lower velocity magnitudes. The filleted flow-guides solve the problem by ensuring even velocity distribution as seen in Figure 17(b). 


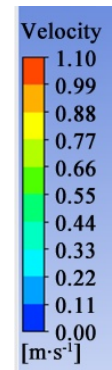

(a)

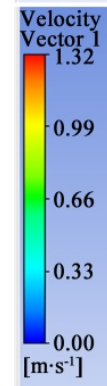

(c)
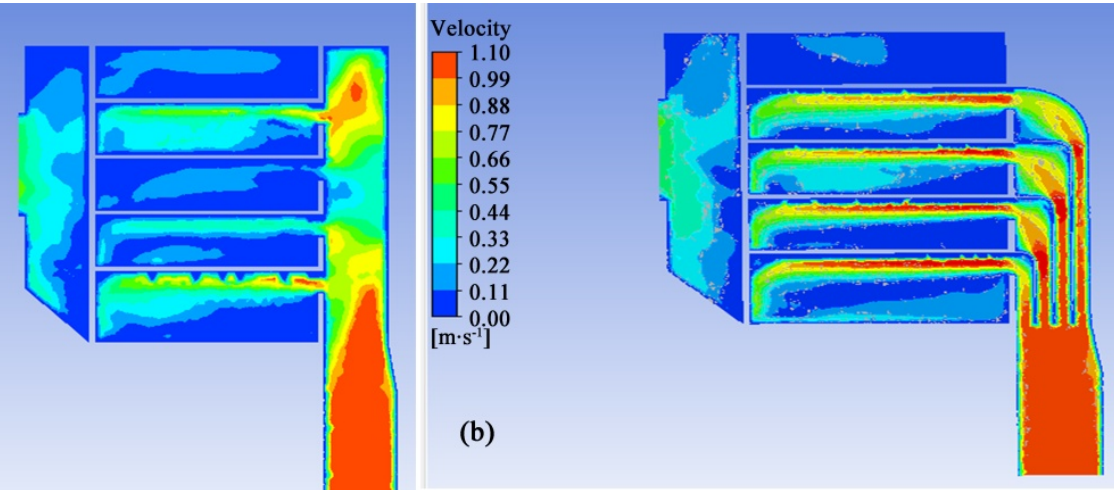

(b)

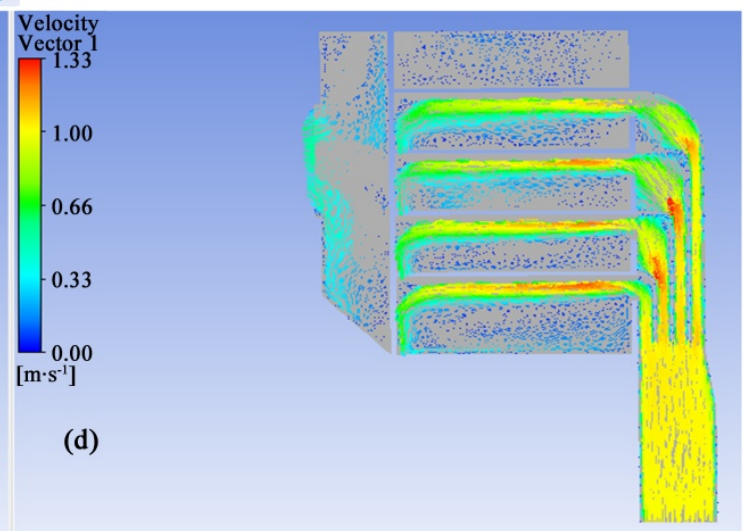

Temperature
\begin{tabular}{|r|}
\hline 54.85 \\
53.69 \\
-52.54 \\
-51.38 \\
-50.22 \\
-49.06 \\
-47.90 \\
-46.75 \\
45.59 \\
-44.43 \\
43.27
\end{tabular}
$[C]$

(e)
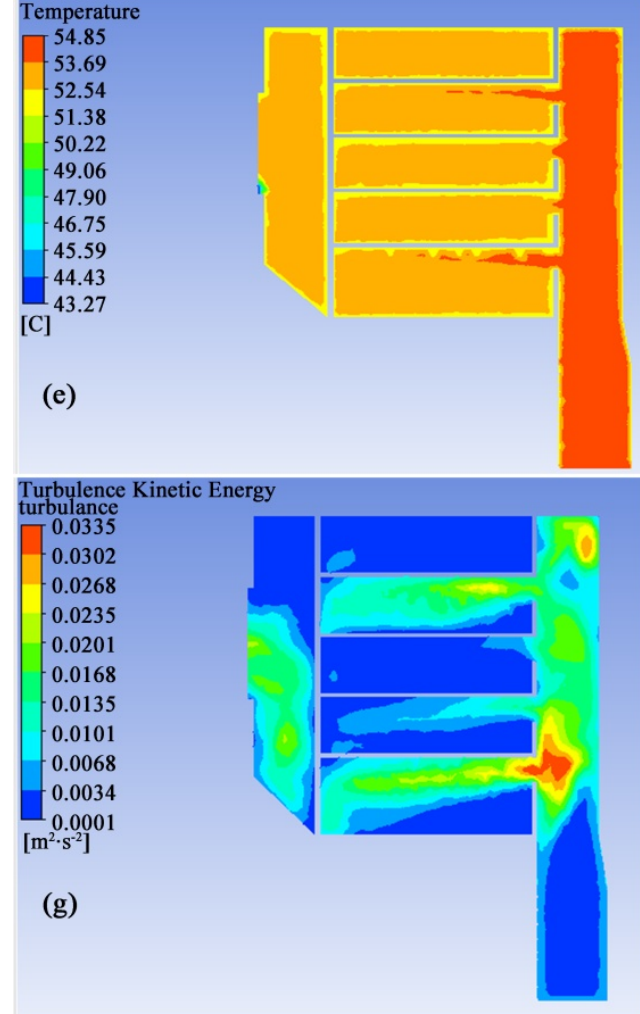
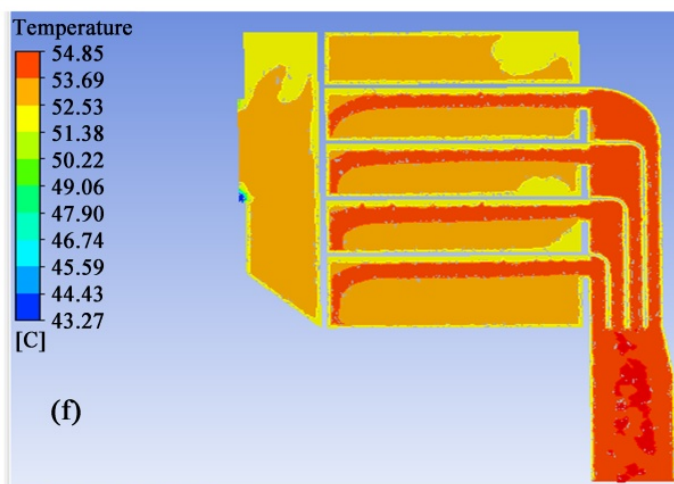

(f)

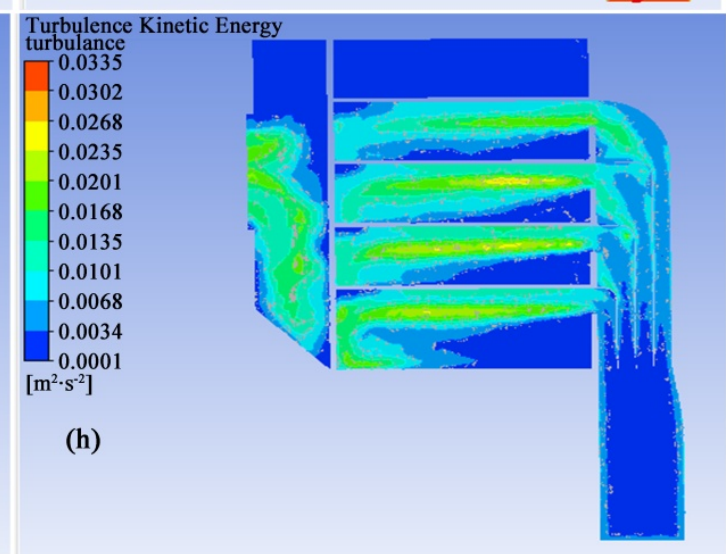

Figure 14. (a) Veloity contours for current dryer; (b) Veloity contours for improved dryer; (c) Velocity vector for current dryer; (d) Velocity vector for improved dryer; (e) Temperature contours for current dryer; (f) Temperature contours for improved dryer; (g) Turbulence contours for current dryer; (h) Turbulene contours for improved dryer. 

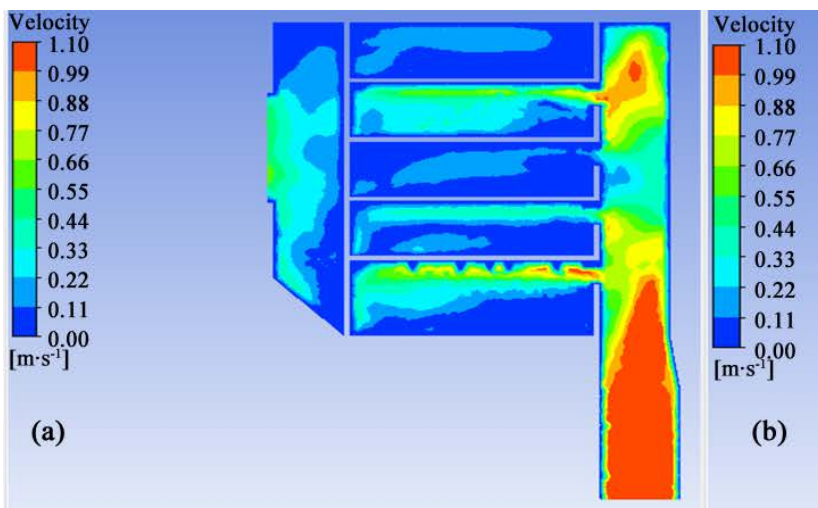

(b)
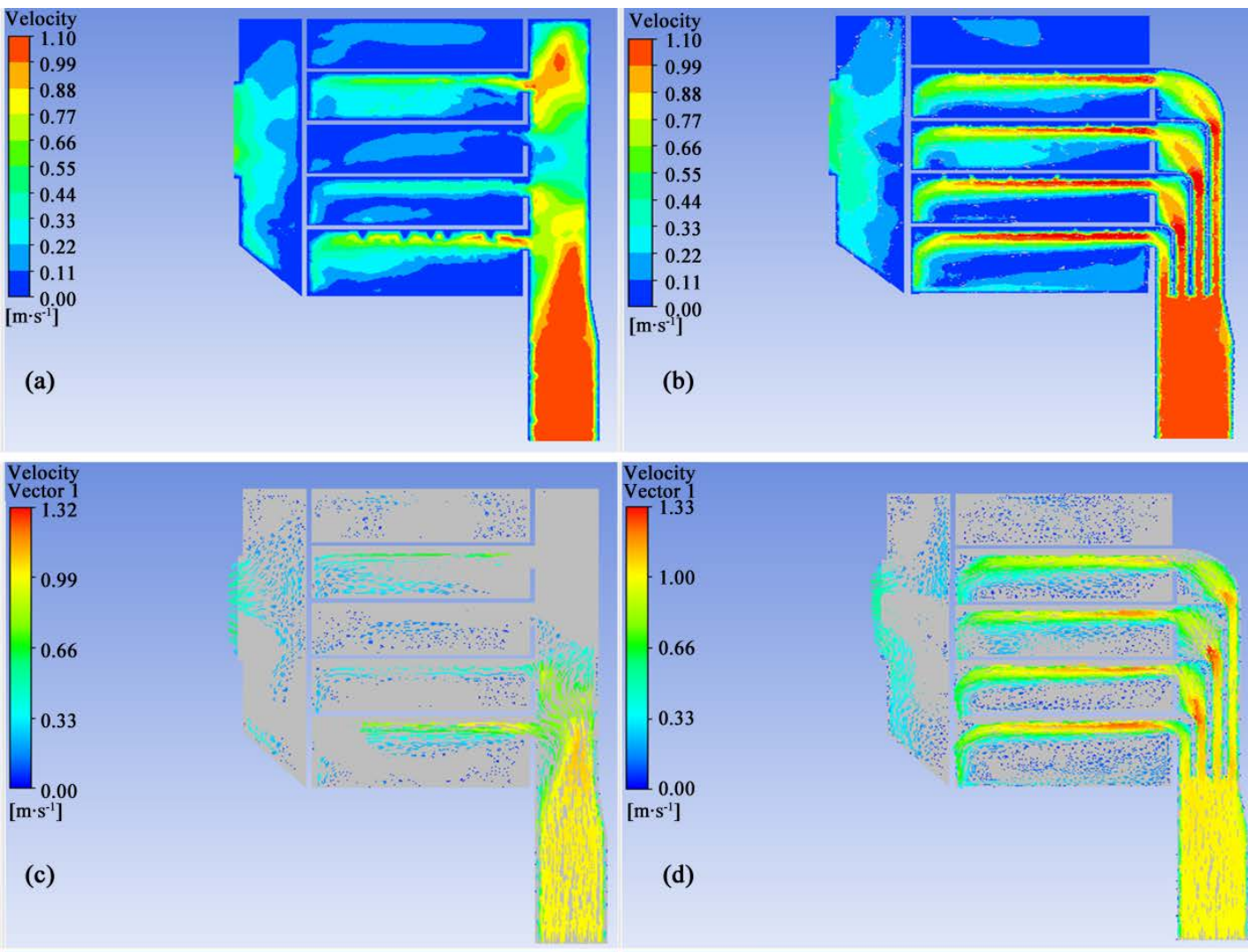

$\left[\mathrm{m} \cdot \mathrm{s}^{-1}\right]$

(d)

Temperature
\begin{tabular}{|r|r|r|}
\hline 44.85 \\
-44.06 \\
-43.27 \\
-42.48 \\
-41.70 \\
-40.91 \\
-40.12 \\
-39.33 \\
-38.54 \\
-37.75 \\
36.96
\end{tabular}
$[C]$

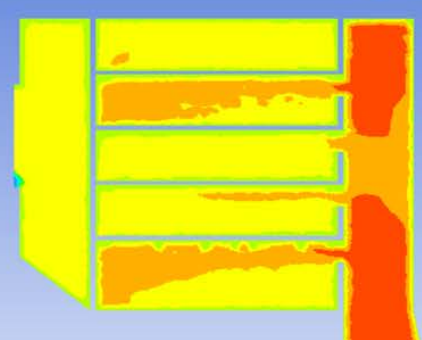

(e)

Temperature
\begin{tabular}{|l|l}
\hline & 44.85 \\
-44.06 \\
-43.27 \\
-42.48 \\
-41.69 \\
-40.90 \\
-40.12 \\
-39.33 \\
38.54 \\
37.75 \\
-36.96
\end{tabular}
[C]

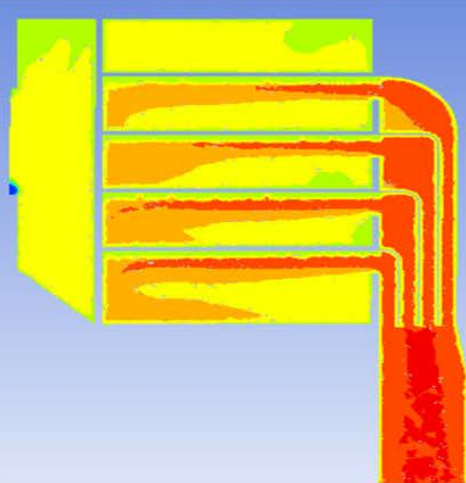

(f)

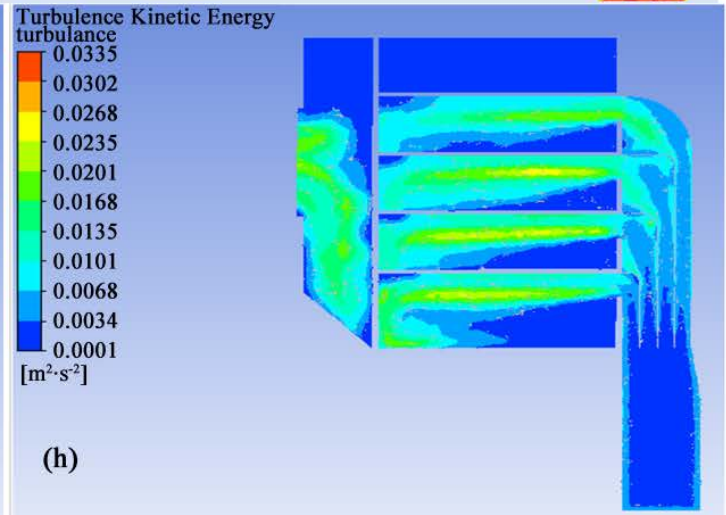

Figure 15. (a) Velocity contours for current dryer; (b) Velocity contours for improved dryer; (c) Velocity vectors for current dryer; (d) Velocity vectors for improved dryer; (e) Temperature contours for current dryer; (f) Temperature contours for improved dryer; (g) Turbulence contours for current dryer; (h) Turbulence contours for improved dryer. 

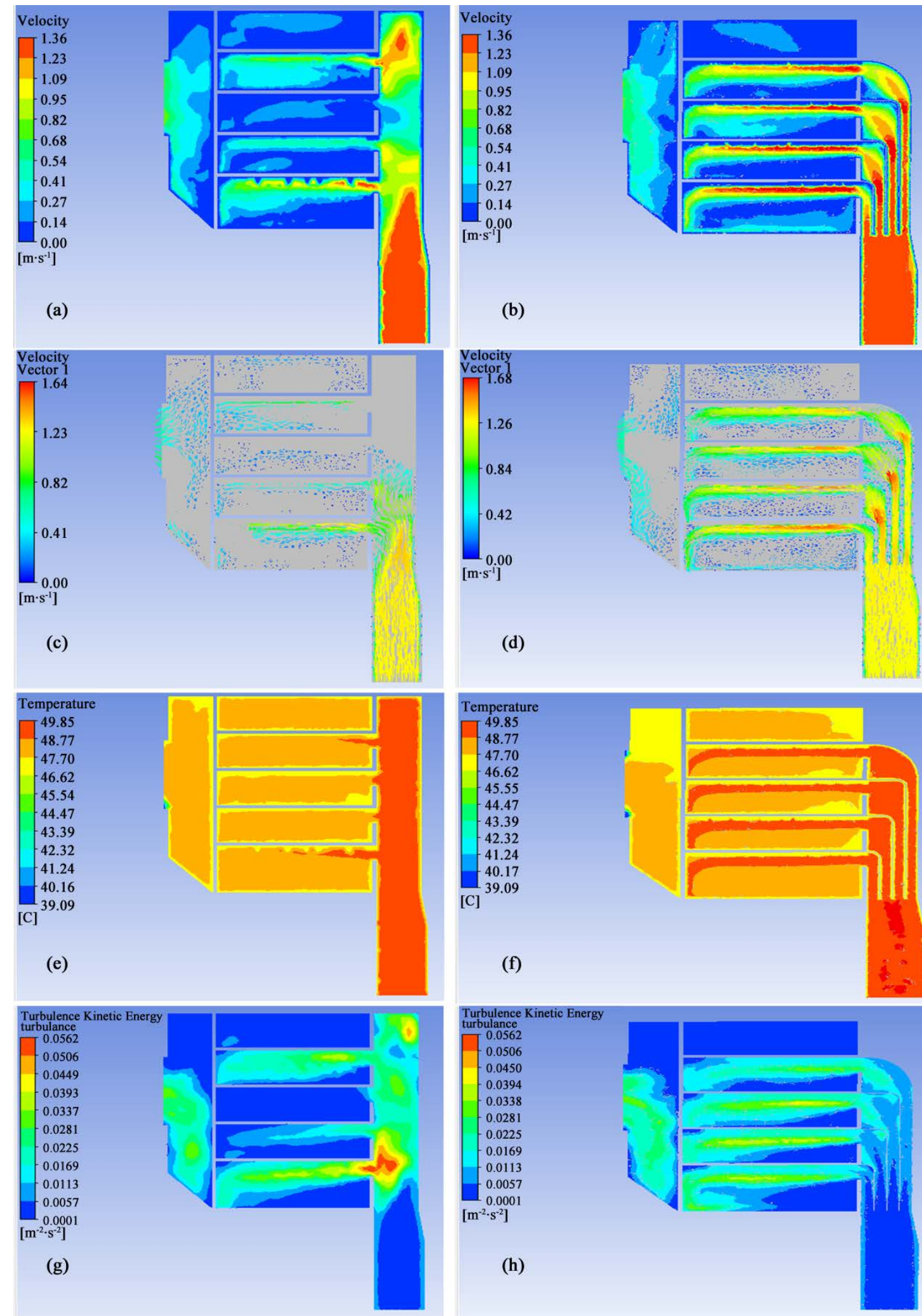

(b)
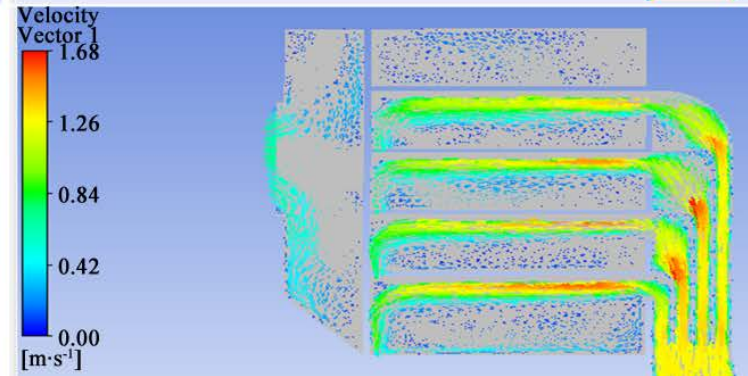

(d)
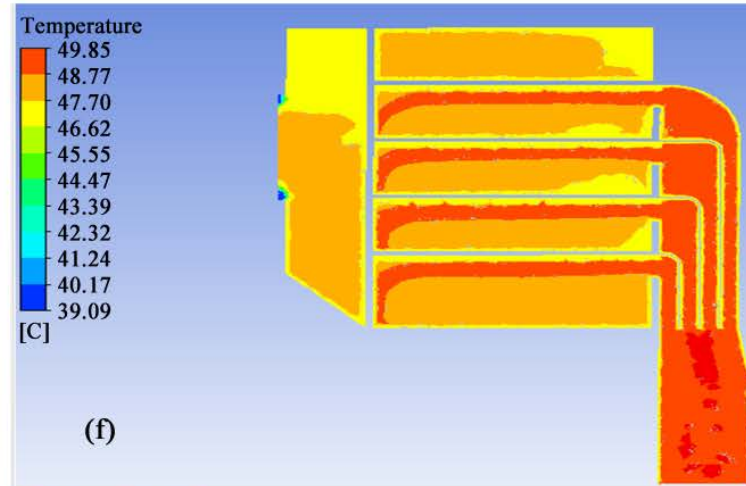

(f)

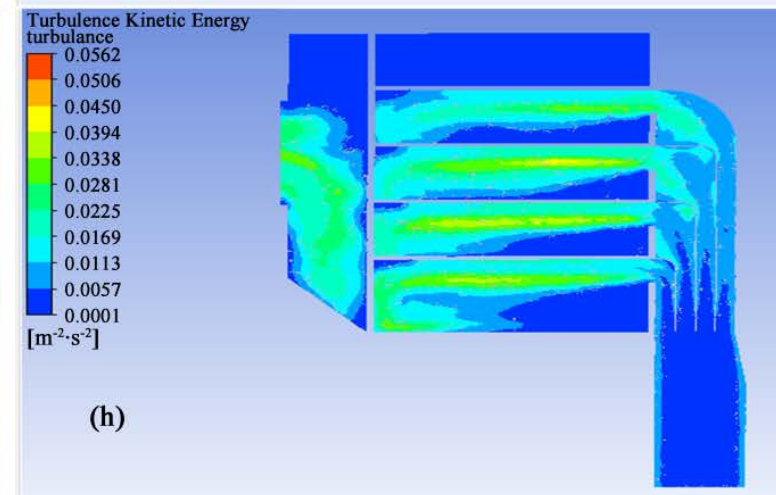

Figure 16. (a) Velocity contours for current dryer; (b) Velocity contours for improved dryer; (c) Veloity vector for current dryer; (d) Veloity vector for improved dryer; (e) Temperature contours for current dryer; (f) Temperature contours for improved dryer; $(\mathrm{g})$ Turbulence contours for current dryer; (h) Turbulence contours for improved dryer. 


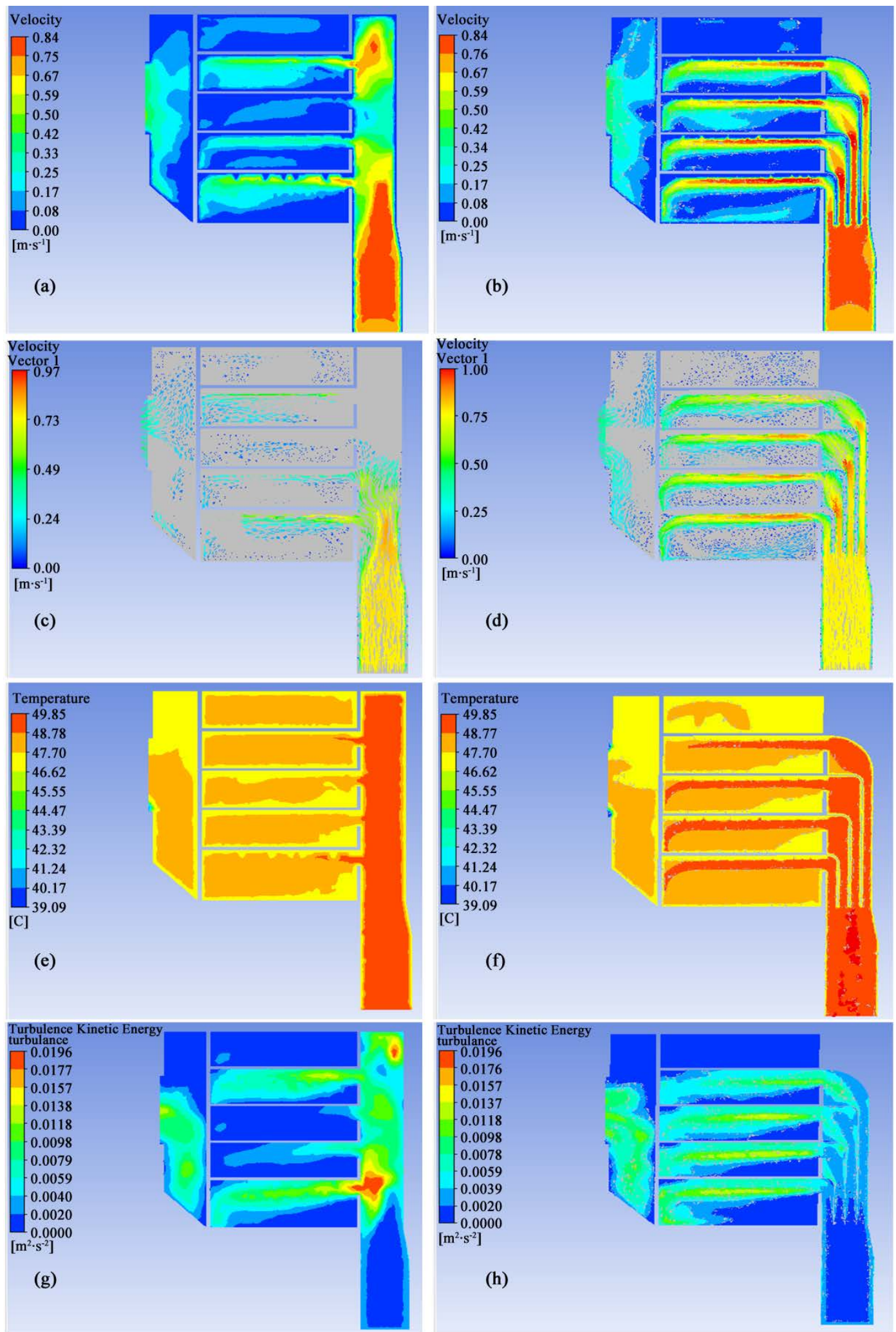

Figure 17. (a) Velocity contours for current dryer; (b) Velocity contours for improved dryer; (c) Velocity vector for current dryer; (d) Velocity vector for improved dryer; (e) Temperature contours for current dryer; (f) Temperature contours for improved dryer; (g) Turbulence contours for current dryer; (h) Turbulence contours for improved dryer. 


\subsection{Velocity and Temperature Distribution}

Table 7 and Table 8 below shows the velocity and temperature magnitudes sampled at the inlet, center, and outlet sections for both current and improved dryer. The average values are also indicated to quantify the percentage increase in magnitude.

\subsubsection{Velocity Distribution}

Figures 18(a)-(d) indicate velocity distribution for current and improved dryer in compartments $1,2,3$, and 4 respectively. The average velocity magnitudes are higher in improved model than in the current dryer. The average velocity magnitude increased by $153.3 \%$ in compartments 1 and 2 . The velocity increased by $176.5 \%$ in compartments 3 and 4 for the modified dyer.

\subsubsection{Temperature Distribution}

The graphs in Figures 19(a)-(d) below show that the improved model has higher temperature distribution across the grain buffer section. The average increase in temperature magnitude was $0.25 \%$ in compartments 1 and 2 . In compartments 3 and 4 , the average temperature increase was $0.22 \%$. The rate of drying is directly proportional to temperature distribution and velocity at which hot air is

Table 7. Velocity $(\mathrm{m} / \mathrm{s})$ distribution.

\begin{tabular}{|c|c|c|c|c|c|c|c|c|}
\hline & \multicolumn{3}{|c|}{ Compartment 1} & \multicolumn{3}{|c|}{ Compartment 2} & \multirow{2}{*}{ Average } & \multirow{2}{*}{$\begin{array}{c}\% \\
\text { increase }\end{array}$} \\
\hline & inlet & center & outlet & inlet & center & outlet & & \\
\hline Current Dryer & 0.383 & 0.683 & 0.443 & 0.254 & 0.368 & 0.223 & 0.392 & \multirow{2}{*}{153.3} \\
\hline \multirow[t]{3}{*}{ Improved Dryer } & 1.163 & 1.120 & 0.740 & 1.167 & 1.087 & 0.682 & 0.993 & \\
\hline & \multicolumn{3}{|c|}{ Compartment 3} & \multicolumn{3}{|c|}{ Compartment 4} & \multirow{2}{*}{ Average } & \multirow{2}{*}{$\begin{array}{c}\% \\
\text { increase }\end{array}$} \\
\hline & inlet & center & outlet & inlet & center & outlet & & \\
\hline Current Dryer & 0.231 & 0.123 & 0.030 & 0.533 & 0.583 & 0.390 & 0.315 & \multirow{2}{*}{176.5} \\
\hline Improved Dryer & 1.000 & 0.987 & 0.602 & 1.067 & 0.920 & 0.650 & 0.871 & \\
\hline
\end{tabular}

Table 8. Temperature (K) distribution.

\begin{tabular}{|c|c|c|c|c|c|c|c|c|}
\hline & \multicolumn{3}{|c|}{ Compartment 1} & \multicolumn{3}{|c|}{ Compartment 2} & \multirow{2}{*}{ Average } & \multirow{2}{*}{$\begin{array}{c}\% \\
\text { increase }\end{array}$} \\
\hline & inlet & center & outlet & inlet & center & outlet & & \\
\hline Current Dryer & 322.5 & 321.5 & 321.7 & 321.9 & 321.4 & 321.3 & 321.7 & \multirow{2}{*}{0.25} \\
\hline \multirow[t]{3}{*}{ Improved Dryer } & 322.7 & 322.4 & 322.1 & 322.9 & 322.5 & 322.2 & 322.5 & \\
\hline & \multicolumn{3}{|c|}{ Compartment 3} & \multicolumn{3}{|c|}{ Compartment 4} & \multirow{2}{*}{ Average } & \multirow{2}{*}{$\begin{array}{c}\% \\
\text { increase }\end{array}$} \\
\hline & inlet & center & outlet & inlet & center & outlet & & \\
\hline Current Dryer & 322.0 & 320.9 & 321.3 & 322.5 & 321.4 & 321.6 & 321.6 & \multirow{2}{*}{0.22} \\
\hline Improved Dryer & 322.7 & 322.3 & 322.0 & 322.4 & 322.2 & 322.0 & 322.3 & \\
\hline
\end{tabular}



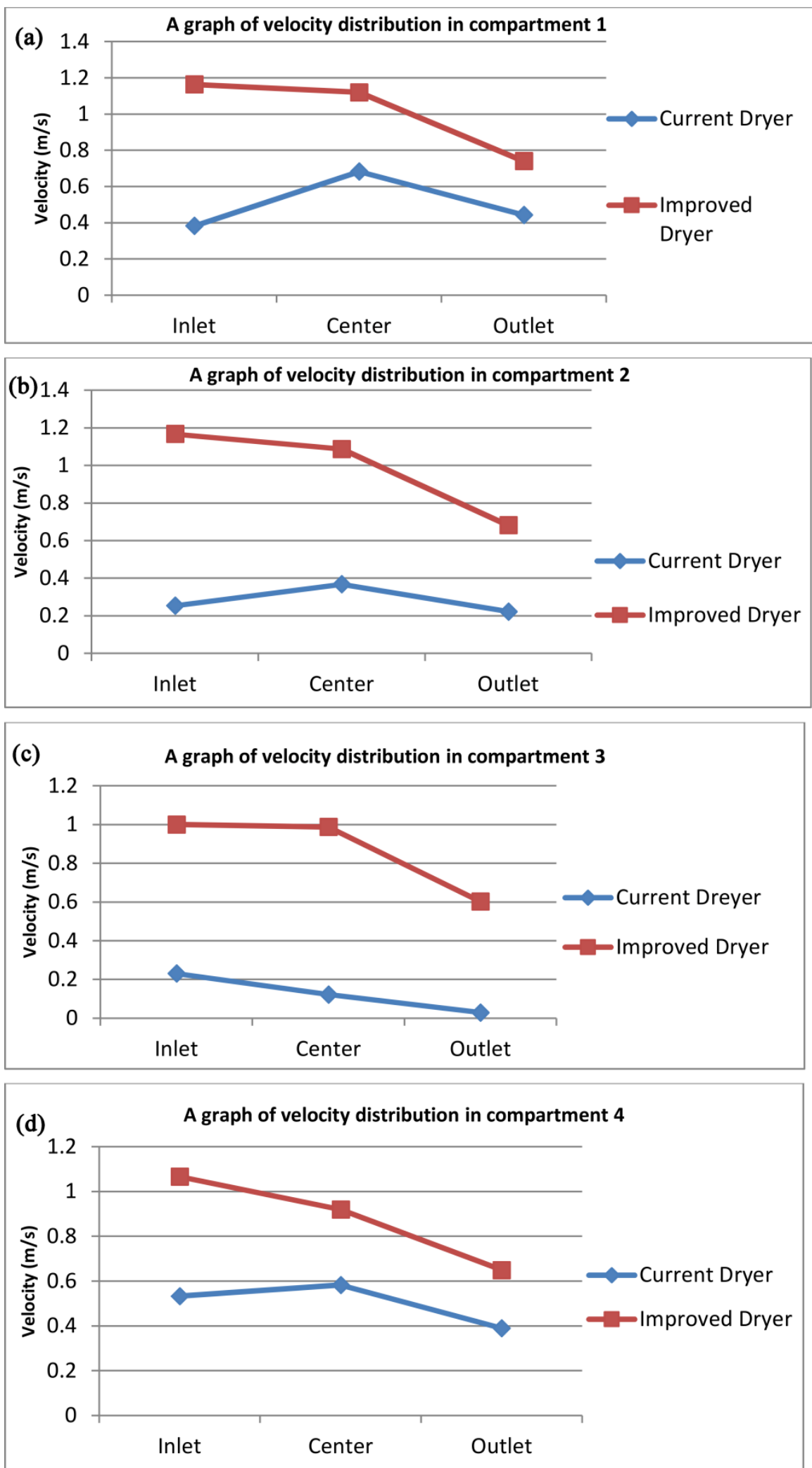

Figure 18. (a) Velocity distribution for current and improved dryer in compartment 1; (b) Velocity distribution for current and improved dryer in compartment 2; (c) Velocity distribution for current and improved dryer in compartment 3; (d) Velocity distribution for current and improved dryer in compartment 4. 

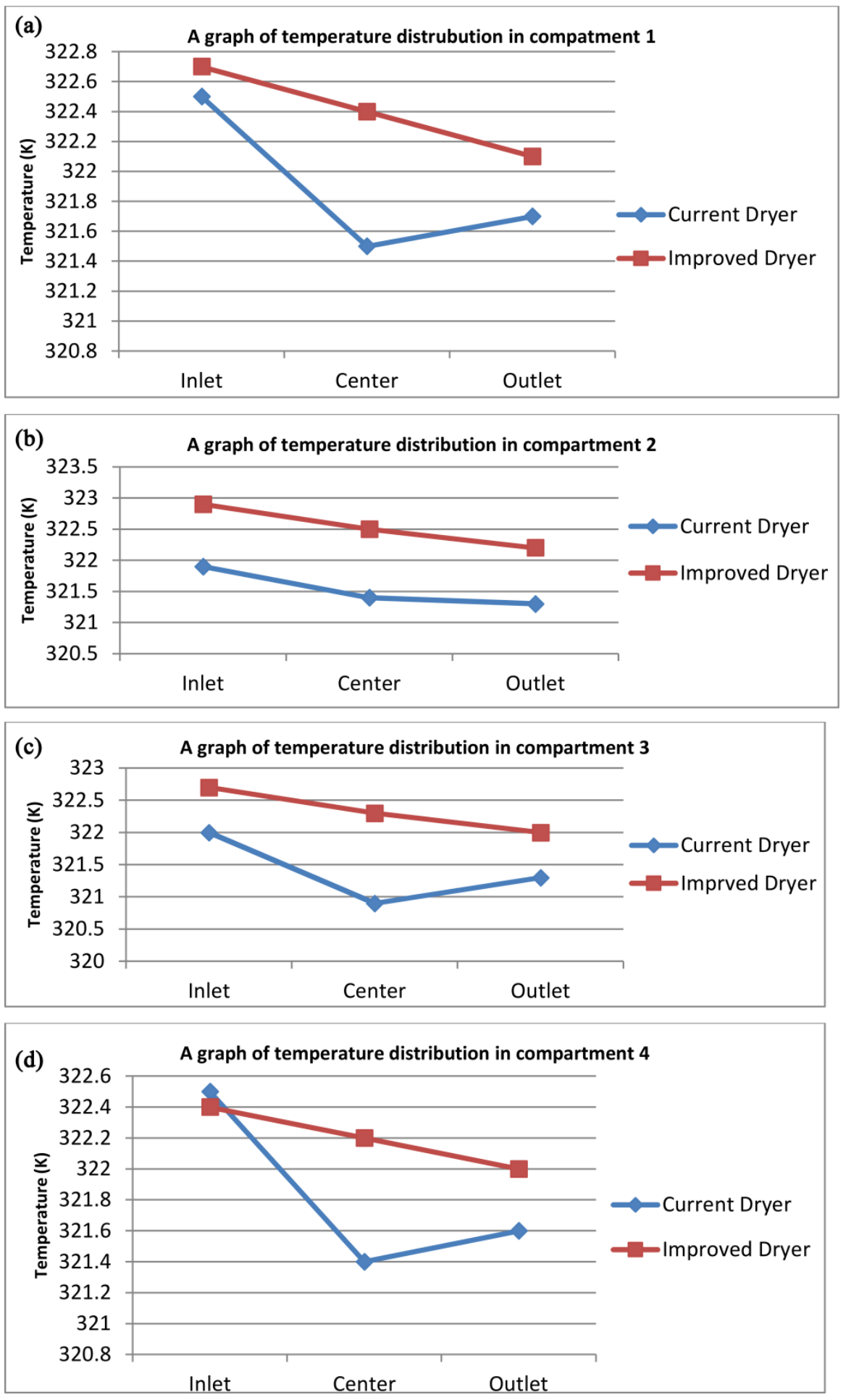

Figure 19. (a) Temperature distribution for current and improved dryer in compartment 1; (b) Temperature distribution for current and improved dryer in compartment 2; (c) Temperature distribution for current and improved dryer in compartment 3; (d) Temperature distribution for current and improved dryer in compartment 4.

blown through the grains [12] [19]. Therefore, the modified dryer would increase drying efficiency by reducing the throughput time. 


\section{Conclusion}

Uneven grain drying and long throughput times are the main challenges encountered in the use of geothermal dryer in Menengai. Experimental results have shown that the grains near the hot air inlet dry at a faster rate than those near the exhaust end. The simulation results attribute uneven grain drying to non-uniform hot air distribution across the grain buffer. Introducing filleted flow-guides at the inlet significantly improves velocity, temperature, and turbulence kinetic energy distribution in the dryer. Based on the simulation results, the filleted flow guides reduce resistance to air flow and also evenly divide the incoming hot air into the four compartments. The velocity and temperature magnitudes across the grain buffer increased when the flow guides were introduced. The average velocity magnitude increased by $153.3 \%$ and $176.5 \%$ in the lower and upper compartments respectively. Similarly, the average temperature magnitude increased by $0.25 \%$ and $0.22 \%$ in the lower and upper compartments respectively for the modified dryer. Therefore, the flow-guides can improve drying efficiency by reducing throughput times and also minimizing the extent of uneven grain drying.

\section{Acknowledgements}

The authors wish to acknowledge support from the Pan African University, Institute for Basic Sciences, Technology, and Innovation for providing financial support for the study. They also thank the Geothermal Development Company for availing its technical staff and the geothermal grain dryer.

\section{Conflicts of Interest}

The authors declare no conflicts of interest regarding the publication of this paper.

\section{References}

[1] Njuguna, E. (2020) Evaluation of Geothermal Grain Dryers: Case Study of Menengai Grain Dryer. 8th African Rift Geothermal Conference (ARGE-C8), Nairobi, 2-6 November 2020, 1-7.

[2] Towett, J., Njuguna, E. and Rotich, B. (2020) Utilization of Geothermal Energy in Agro-Based Industries: Case Study of Geothermal Grain Dryer in Menengai Geothermal Field. 8th African Rift Geothermal Conference (ARGE-C8), Nairobi, 2-6 November 2020, 1-6.

[3] Van Nguyen, M., Arason, S., Gissurarson, M. and Pálsson, P.G. (2015) Uses of Geothermal Energy in Food and Agriculture. Opportunities for Developing Countries. FAO, Rome.

[4] Ndetei, C.J. (2016) Opportunities for Direct Utilization of Geothermal Energy in Eburru Area, Nakuru County in Kenya. Proceedings of the 6th African Rift Geothermal Conference, Addis Ababa, 2-4 November 2016, 1-10.

[5] Popovski, K. and Popovska-Vasilevska, S. (2004) Geothermal Energy Use in Macedonia. International Geothermal Days POLAND 2004, Zakopane, 13-17 September 2004, 284-294. 
[6] Abdullah, K. and Gunadnya, I.B.P. (2010) Use of Geothermal Energy for Drying and Cooling Purposes. Proceedings World Geothermal Congress, Bali, 25-29 April 2010, 1-5.

[7] Kinyanjui, S. (2013) Direct Use of Geothermal Energy in Menengai, Kenya: Proposed Geothermal Spa and Crop Drying. Geothermal Training Programme No. 9.

[8] Dyck, J. and Eng, P. (2017) Reducing Energy Use in Grain Dryers. Ministry of Agriculture, Food and Rural Affairs, Ontario.

[9] Helvac1, H.U. and Akkurt, G.G. (2014) Thermodynamic Performance Evaluation of a Geothermal Drying System. In: Dincer, I., Midilli, A. and Kucuk, H., Eds., Progress in Exergy, Energy, and the Environment, Springer, Cham, 331-341. https://doi.org/10.1007/978-3-319-04681-5_29

[10] Wang, G.Y., Wu, W.F., Qiao, F.X., Fu, D.P., Liu, Z. and Han, F. (2020) Research on an Electric Energy-Saving Grain Drying System with Internal Circulation of the Drying Medium. Journal of Food Process Engineering, 43, e13476. https://doi.org/10.1111/jfpe.13476

[11] Ma, M.J. and Rosentrater, K.A. (2019) Techno-Economic Analysis (TEA) and Life Cycle Assessment (LCA) of a Low Temperature Closed-Cycle Grain Drying System. Journal of Agricultural Science, 11, 52-62.

[12] Akhtaruzzaman, M., Mondal, M.H.T., Biswas, M., Sheikh, M.A.M., Khatun, A.A. and Sarker, M.S.H. (2021) Evaluation of Drying Performance, Energy Consumption, and Quality of Two-Stage Dried Maize Grain. Journal of Biosystems Engineering, 46, 151-162. https://doi.org/10.1007/s42853-021-00095-w

[13] Nowak, J. and Przystupa, W. (2019) Methods for Assessing Energy Efficiency of Grain Dryers. Agricultural Engineering, 23, 39-47.

[14] Wang, D. and Chang, C.S. (2001) Energy Efficiency of a New Heat Pump System for Drying Grain. Transactions of the American Society of Agricultural Engineers, 44, 1745-1750. https://doi.org/10.13031/2013.6987

[15] Dębowski, M., Bukowski, P., Kobel, P., Bieniek, J., Romański, L. and Knutel, B. (2021) Comparison of Energy Consumption of Cereal Grain Dryer Powered by LPG and Hard Coal in Polish Conditions. Energies, 14, Article No. 4340. https://doi.org/10.3390/en14144340

[16] Wang, G.Y., Wu, W.F., Fu, D.P., Xu, W., Xu, Y. and Zhang, Y.Q. (2022) Energy and Exergy Analyses of Rice Drying in a Novel Electric Stationary Bed Grain-Drying System with Internal Circulation of the Drying Medium. Foods, 11, Article No. 101. https://doi.org/10.3390/foods11010101

[17] Stephen, A.K. and Emmanuel, S. (2009) Improvement on the Design of a Cabinet Grain Dryer. American Journal of Engineering and Applied Sciences, 2, 217-228.

[18] Versteeg, H.K. and Malalasekera, W. (2007) An Introduction to Computational Fluid Dynamics: The Finite Volume Method. Pearson Education, London.

[19] Bola, F.A., Bukola, A.F., Olanrewaju, I.S. and Adisa, S.B. (2013) Design Parameters for a Small-Scale Batch In-Bin Maize Dryer. Agricultural Sciences, 4, 90-95. https://doi.org/10.4236/as.2013.45B017 